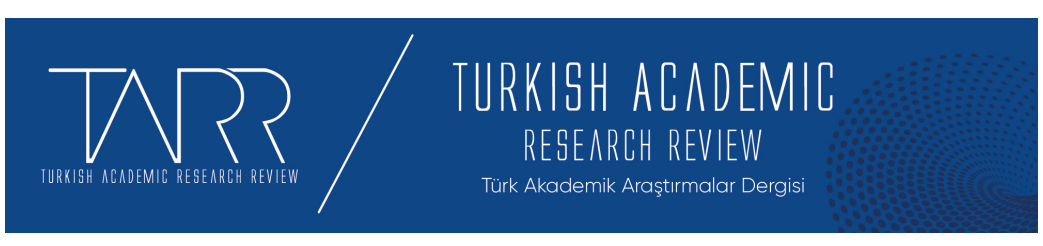

e-ISSN: 2602-2923 Yil/Year: 2021 Cilt/Volume: 6 Sayı/Issue: 4

\title{
Dijitalleşen Dünyada Anlam Arayışı: Altın Çağ Şifa Teknikleri Örneği
}

Man's Search for Meaning in A Digitalized World: The Example of Golden Age Healing Techniques

\section{Merve BAHADUR - İhsan ÇAPCIOĞLU}

Doktora Öğrencisi, Ankara Üniversitesi Sosyal Bilimler Enstitüsü, Felsefe ve Din Bilimleri (Din Sosyolojisi) Anabilim Dalı/Ankara University, Social Science Institute, Department of Philosophy and Religious Sciences (Sociology of Religion), uysalmerve_32@hotmail.com, Orcid ID: https://orcid.org/ 0000-0001-6377-2081

Prof. Dr., Ankara Üniversitesi İlahiyat Fakültesi, Felsefe ve Din Bilimleri Din Sosyolojisi Anabilim Dalı/Ankara University, Faculty of Divinity, Department of Philosophy and Religious Sciences (Sociology of Religion), ihsancapcioglu@yahoo.com, Orcid ID: https://orcid.org/ 0000-0003-4796-5232

\begin{tabular}{r|l} 
Makale Bilgisi & Article Information \\
Makale Türü - Article Type & Araştırma Makalesi / Research Article \\
Geliş Tarihi - Date Received & 30 Ekim / October 2021 \\
Kabul Tarihi - Date Accepted & 25 Aralık / December 2021 \\
Yayın Tarihi - Date Published & 31 Aralık / December 2021 \\
Yayın Sezonu & Aralık Özel Sayı \\
Pub Date Season & December Special Issue
\end{tabular}

Atıf / Cite as: Bahadur, M. - Çapcıŏlu, İ. (2021), Dijitalleşen Dünyada Anlam Arayış1: Altın Çağ Şifa Teknikleri Örneği/ Man's Search for Meaning in A Digitalized World: The Example of Golden Age Healing Techniques. Turkish Academic Research $\begin{array}{lllll}\text { Review, } & 6 & \text { (4), } & 147-177 . & \text { Retrieved }\end{array}$ https://dergipark.org.tr/tr/pub/tarr/issue/67631/1016671

Intihal / Plagiarism: Bu makale, en az iki hakem tarafından incelenmiş ve intihal içermediği teyit edilmiştir. / This article has been reviewed by at least two referees and confirmed to include no plagiarism. https://dergipark.org.tr/tr/pub/tarr

Copyright (C) Published by Mehmet ŞAHIN Since 2016- Akdeniz University, Faculty of Theology, Antalya, 07058 Turkey. All rights reserved.

Turkish Academic Research Review - Türk Akademik Araştırmalar Dergisi 


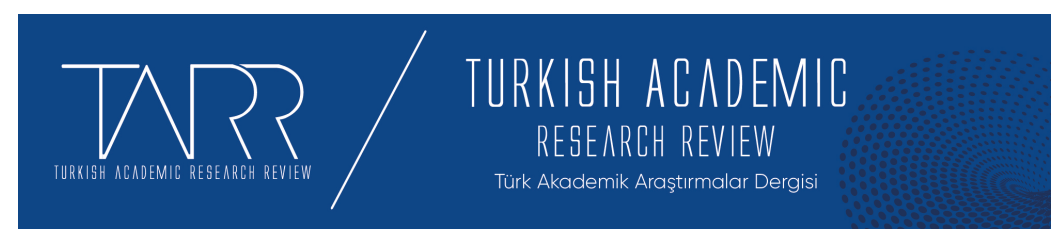

e-ISSN: 2602-2923 Yil/Year: $2021 \quad$ Cilt/Volume: 6 Sayı/Issue: 4

\title{
Dijitalleşen Dünyada Anlam Arayışı: Altın Çağ Şifa Teknikleri Örneği
}

\author{
Merve BAHADUR - İhsan ÇAPCIOĞLU
}

Öz

İnsanın anlam arayışına nitelikli cevaplar bulma imkanı sunan dini düşünce, inanç ve ritüel eksenli yönelimleri gündelik hayatının ayrılmaz bir parçası olmuştur. Sekülerleşen dünyada insanın söz konusu arayışı yeni dini hareketler olgusunu gündeme getirmiştir. İnsan, manevi boşluğunu ve anlam arayışını doldurmak için modern kutsal rehberlere ihtiyaç duymaktadır. Bu amaçla faaliyetlerde bulunan yeni dini hareketler senkretik ve eklektik oluşumlar olarak tüm dünyada yayılmaktadır. Yeni dini hareketlerin metafizik yönünü temsil eden ve 1970'lerin başlarında görünürlük kazanan astroloji, yoga, reiki, bilinçaltı, kuantum ve biyoenerji gibi mistik deneyimler; din ile maneviyatın iç içe geçtiğini göstermektedir. İnternet tabanlı sosyal ağlarda ve özellikle sosyal medyada bu hareketlerin etki alanını her geçen gün genişletmesi, dijital platformların dinsel amaçlarla kullanılmasını ve dinin dijitalleşmesini beraberinde getirmektedir. Sosyal ağlarda icra edilen çevrimiçi dini ritüeller; şifa, enerji alanını güçlendirme teknikleri, yaşam çiçeği ve frekanslar gibi uygulamalar yoluyla arayış içindeki bireyleri kendisine çekmeyi başarmaktadır. Bu çalışma, Doğu Asya geleneklerinden beslenen ve son dönemde dijital platformlarda tamamlayıcı tedavi teknikleri kapsamında popülerlik kazanan yaşam çiçeği ile beden şifası uygulamasını konu edinmektedir. Çalışma, dijital dini sosyalleşme platformu olan 'Ferhan Sezer Altın Çağın Şifa Teknikleri', 'FS Yaşam Çiçeği Şifası' adlı Instagram hesabındaki 548 gönderiden yaşam çiçeği ile şifalanma, para okulu, özel kodlamalı altın çağ şifa takıları olarak üç kategoride (dini ve fikhi bağlayıcılık, göz ve dünya tasavvuru, akışkan tüketim) ele alınmaktadır. Gönderilerin büyük çoğunluğu metin içerikli olmakla birlikte araştırma, 31 Temmuz 2021'den 31 Ekim'e kadarki üç aylık süreçte incelenmektedir. Intagram hesabından yapılan paylaşımlar, dinsel söylemlere ve çevrimiçi ritüellere nitel araştırma tekniklerinden söylem analizi ile odaklanılmaktadır.

Anahtar Kelimeler: İnsanın anlam arayışı, dijitalleşme, yeni çağ akımları, çevrimiçi ritüeller, altın çağ şifa teknikleri.

\section{Man's Search for Meaning in A Digitalized World: The Example of Golden Age Healing Techniques}

\begin{abstract}
Religious thought, faith and ritual-oriented orientations, which provide the opportunity to find qualified answers to a person's search for meaning, have become an integral part of his everyday life. In the secularized world, the search for a person in question has brought up the phenomenon of new religious movements. Man needs modern sacred guides to fill his spiritual emptiness and the search for meaning. New
\end{abstract}

Turkish Academic Research Review - Türk Akademik Araştırmalar Dergisi 
religious movements that are engaged in activities for this purpose are spreading all over the world with syncretic and eclectic formation. Mystical experiences such as astrology, yoga, reiki, the subconscious, quantum and bioenergy, which represent the metaphysical aspect of new religious movements and gained visibility in the early 1970's, show that religion and spirituality are intertwined. The expansion of the sphere of influence of these movements in Internet-based social networks and especially in social media every day leads to the use of digital platforms for religious purposes and the digitalization of religion. Online religious rituals performed on social networks; healing, techniques for strengthening the energy field, the flower of life and frequencies, such as practices such as attracting individuals in search of it. This study focuses on the application of body healing with the flower of life, which is fed by East Asian traditions and has recently gained popularity within the scope of complementary treatment techniques on digital platforms. The study is examined in three categories (religious binding, eye and world conception, fluid consumption) as healing with the flower of life, money school, golden age healing jewelry with special coding from 548 posts on the Instagram account 'Ferhan Sezer Golden Age Healing Techniques', 'FS Life Flower Healing', a digital religious socialization platform. Although the vast majority of the submissions are text-based, the research is being examined in the three-month period from July 31, 2021 to October 31. The shares made from the Instagram account are focused on religious discourses and online rituals with discourse analysis, which is a qualitative research technique.

Keywords: Man's search for meaning, digitalization, new age movements, online rituals, golden age healing techniques.

\section{Structured Abstract}

The New Religious Movements (NRMs), whose prevalence has been increasing since the middle of the last century, have formed the basis of new searches for the sacred, contrary to the dichotomous structure presented to modern people. The search for lost meaning has paved the way for the emergence of New Age Movements with new conceptualizations such as religious ascension, the return of the sacred, religious fundamentalism and pluralism. As modern man moves away from the holy, he needs modern holy guides to fill the spiritual void and search for meaning. New Age Movements, which carry out activities for this purpose, are a syncretic and eclectic formation that emerged in Western society and spread all over the world over time. The New Age Movement, which started to become widespread in Turkey in the 1960s, started to rise with energy healing activities, especially in the 2000s. Modern healing techniques such as 'reiki, theta healing, bioenergy, access bars, eft and flower of life' have gained importance in Turkey. Mystical experiences such as astrology, yoga, reiki, subconscious, quantum and bioenergy, which represent the metaphysical aspect of the new religious movements and became visible in the early 1970s; It shows that religion and spirituality are intertwined. The widening of the influence of these movements in internet-based social networks and especially in social media brings with it the use of digital platforms for religious purposes and the digitalization of religion.

Sharing from social network accounts, live broadcasts, IGTV videos and gift sessions on social media, which play an active role in the spread of modern healing techniques, promise to fill the spiritual void in individuals. Thus, New Age Movements, which are defined as 'mystical experiences, secular spirituality or alternative holiness', can find their place in the media and deliver their messages to large masses, and the number of religious-looking spiritualist groups is increasing day by day with the 
opportunities offered by the new media. This study deals with the practice of body healing with the flower of life, which is fed by East Asian traditions and has gained popularity in the scope of complementary alternative therapy techniques on digital platforms recently. The Golden Age Healing Techniques, which try to produce an answer to the individual's search for meaning with the promise of spiritual satisfaction, are discussed. The visibility of healer practices in social media is examined in the context of Golden Age Healing Techniques (body healing with the flower of life), an energy healing movement known for its online healing practices on digital platforms. The study will be held on 31 July 2021 in three categories as healing with flower of life, money school, special coded golden age healing jewelry from 548 posts titled "Ferhan Sezer Golden Age Healing Techniques", "FS Flower of Life Healing" on Instagram account as a digital religious socialization platform. It is evaluated in the context of religious-spiritual discourse and online rituals in the posts shared open to all users, with discourse analysis, which is a qualitative research technique, within the three-month period from October 31 to July 31.

The Golden Age Healing Techniques, which are described as a first in the world, claim that they offer a heavenly life with symbols and actions, using both a secular and religious style. Thus, the founder Ferhan Sezer makes the symbol of the flower of life usable techniques for body and life healing and offers both collective and online counseling and training. It gives applications with brain, body healing, water healing, healing coded words and products, spiritual, energetic, frequency and vibrations. Ferhan Sezer, who invites himself to the heaven within you in the chaos of the world, shares his rituals (such as F. S. Golden Age's healing techniques, flower of life, body healing and coding) in the online space (Instagram) in order to catch the truth on the way to become a real human, to be purified and to be invited to heaven on earth. Healing with the flower of life, money school, "fiqhi binding", "eye-centered world vision" and "fluid consumption" as special coded golden age healing jewelry from 548 posts on Ferhan Sezer Golden Age Healing Techniques, FS Flower of Life Healing page on his Instagram account. are considered in three categories. The language and discourses used ("I wake up from heaven", "I am in the frequency of gratitude"), the symbols in the products sold (flower of life designed painting, wallet and necklaces) are identified with the mystical spiritist structure of paganist and far eastern philosophy. When the visual and textual shares are examined, it is seen that they take place in the New Age Movement, which is one of the religious movement areas. It also includes an occultist, esoteric mission. It is open to debate whether this group/formation/cult, as in the New Age Movement, is a religious movement, a movement that puts people in the center, offers healing techniques with the energy in the universe, promises salvation and inner awakening. Although it is not seen as a religious movement in that it does not have a central government and a charismatic leader, it has a religious character and structure in terms of being a secular spiritual subculture.

Turkish Academic Research Review - Türk Akademik Araştırmalar Dergisi 


\section{Giriş}

Modern dönemde çeşitli düşünce akımlarının etkisiyle toplumsal hayatta radikal değişimlerin ortaya çıktığı bilinmektedir. Bu değişimler pek çok kurumsal yapılanmada olduğu gibi din kurumunun da geleneksel olarak yerine getirdiği işlevlerin sürdürülmesi konusunda çeşitli zorlukları beraberinde getirmiştir. Toplumsal kurumlara duyulan güvenin sarsılarak insanlar arası ilişkileri düzenleyen normların zayıflaması, yeni dini arayışlara kapı aralamıştır. Modernleşme, sekülerleşme, rasyonelleşme ve bireyselleşme gibi toplumsal süreçlerin etkisiyle kutsal olan sorgulanmış ve yerini kutsal dışı ya da profan olana bırakmış, modern insanın ihtiyaçlarını karşılayacak yeni inanç ve akımlar ortaya çıkmıştır. Modernleşme sürecinde dinin zayıflayacağına ilişkin öngörüler ve tartışmalar, 1960'l1 yıllardan itibaren yeni bir olgunun yükselişine yol açmış ve yeni dini hareketler ortaya çıkmaya başlamıştır (Şentürk, 2004: 56-8). Weber'in tabiriyle 'dünyanın büyüsünün bozulması'yla (Weber, 2010, 2011) bireyin Tanrı ile olan ilişkisinin kurumlar tarafından değil de bireyin kendisi tarafından belirlendiği, dini konularda özgürce düşünme ve tartışma hakkının olduğu yeni bir alan doğmuştur (Ünal, 2011: 65).

Modernleşmenin aklın egemenliğine dayalı bir düzeni savunarak kutsal ve sezgisel olanı kamusal alanın sınırları dışında tutması, birey merkezli bir düşünceyi sistematize eden süreçlerin başlangıcını oluşturmuştur (Mirza, 2018: 69-70; Çapcıoğlu, 2017a). Bu sürecin beraberinde getirdiği sekülerleşme, dini kurumların itibarını azaltarak bireyin hem öznel yaşantılarını hem de toplumsal varoluşunu dine ihtiyaç duymadan da sürdürebileceği kanaatini yerleştirmiştir (Berger-Luckmann, 2015: 53). Ancak bireyin merkeze alınarak kutsalın dışlandığı böyle bir toplumsal yapılanmada beklentilerin karşılanamaması, modern insanı her geçen gün daha da yalnızlaştırmıştır. Bireyin dünyasında oluşan derin varoluşsal boşluk ve kaygılar; 'seküler ruhsallıklar -seküler ezoterizm, okültizm (Hanegraff, 1999: 152), alternatif kutsallıklar ve terapi kültleri' (Kirman, 2010: 284) gibi akımlar tarafindan doldurulmaya çalışılmıştır.

Geçtiğimiz yüzyılın ortalarından itibaren yaygınlığı giderek artan Yeni Dini Hareketler (YDH), modern insana sunulan dikotomik yapının aksine kutsala yönelik yeni arayışların zeminini oluşturmuştur (Mirza, 2018: 18). YDH'ler, kimi zaman yeni dini organizasyonlar ve alternatif dini hareketler, kimi zaman da pejoratif anlamlar atfedilerek 'kült' olarak nitelendirilmiştir (Zuckerman, 2010). İlk örneklerine 
1960'larda Batı toplumlarında rastlanan, 1970'li yıllarda görünürlüğü gittikçe artan ve 1980'lerde etkinliği kısmen azalan bu hareketler, son yıllarda dini açıdan çoğulcu, eklektik formlar altında ve yeni manevi arayışlara yönelme şeklinde yeniden kendini göstermiştir (Uluç, 2013: 105; Çapcioğlu, 2016: 325-340). YDH'ler bir taraftan yayılmaya devam ederken diğer taraftan yeni düşünce ve tecrübelerle kuşatılan modern birey, Yeni Çağ (New Age) Akımı (YÇA) olarak adlandırılan ve kadim ruhsal öğretilerin yanı sıra Hint ve Uzak Doğu dinlerinin mistik felsefelerinden (Arslan, 2006: 13) beslenen maneviyatçı akımlar tarafından kuşatılmıştır. Söz konusu öğretilerin yaygınlaştırdığı modern şifa tekniklerinin görünürlüğü halen artmaya devam etmektedir. Bu çerçevede modern şifacılık tekniklerinden olan enerji şifacılı̆̆g, bireylerin her türlü problemlerinin çözüleceği inancını yaygınlaştırmaktadır (Erdoğan ve Çınar, 2011: 87). Anlam arayışını sürdüren birey, enerji tekniklerinden haberdar olmak istemekte ve sosyal ağlar üzerinden organize edilen şifa grupları aracılığıyla bir kolektivitenin üyesi haline gelmektedir.

Yeni Çağ Akımları (YÇA) özellikle 2000'li yıllarda enerji şifacılığı faaliyetleri ile yükselişe geçmiştir. Ülkemizde 'reiki, theta healing, biyoenerji, access bars, eft ve yaşam çiçeği' gibi modern şifa teknikleri önem kazanmıştır. Modern şifa tekniklerinin yaygınlaşmasında aktif rol oynayan sosyal medyadaki sosyal ağ hesaplarından yapılan paylaşımlar, canlı yayın, IGTV videoları ve hediye seanslar bireylerdeki manevi boşluğu doldurmayı vadetmektedir. Böylece 'mistik deneyimler, seküler maneviyat ya da alternatif ruhsallıklar' olarak tanımlanan YÇA'lar, medyada kendilerine yer bularak mesajlarını geniş kitlelere ulaştırabilmekte ve yeni medyanın sunduğu imkânlar ile dinsel görünümlü maneviyatçı grupların sayısı her geçen gün artmaktadır. $\mathrm{Bu}$ çalışmada manevi açıdan doyuma ulaştırma vaadiyle bireyin anlam arayışına cevap üretmeye çalışan Altın Çağ Şifa Teknikleri ele alınmaktadır. Dijital platformlardaki çevrimiçi şifa uygulamaları ile bilinen bir enerji şifacılı̆̆ı hareketi olan Altın Çağ Şifa Teknikleri (yaşam çiçeği ile beden şifalanması) bağlamında şifacı pratiklerin sosyal medyadaki görünürlüğü incelenmektedir. "Ferhan Sezer Altın Çağ Şifa Teknikleri” başlıklı Instagram hesabı, özellikle din-manevi söylem ve çevrimiçi ritüeller bağlamında değerlendirilmektedir.

\section{İnsanın Anlam Arayışı ve Yeni Çağ Akımları}

İnsanın anlam arayışındaki anlam sözcüğü beşeri varoluşun özünü ifade etmektedir. Yaşam boyu devam eden bu arayışın sonucunda hakikatin bilgisine ulaşma isteği, insanın belirsizlikten kurtulup hayattaki konumunu tayin etmesi bakımından önem arz etmektedir (Çapcıoğlu ve Yürük, 2010: 22-5; ayrıca bkz. Çapcıoğlu, 2020a). Çünkü insan, hayatı anlamlı kılma çabası içinde olan bir varlıktır.

Turkish Academic Research Review - Türk Akademik Araştırmalar Dergisi https://dergipark.org.tr/tr/pub/tarr 
Onun kendisine anlamlı bir dünya kurma girişimi; dışsallaştırma, nesnelleştirme ve içselleştirmeden oluşan temel diyalektik süreçlerde (Berger, 2011: 53) gerçekleşmektedir. Bu süreçlerde bireyin anlam dünyasında yaşadığı krizlerin çözümlenmesi ise stratejik rol oynamaktadır (Berger, 2011: 88). Çünkü insan tamamlanmamış bir varlık olduğu için kendi dünyasını yine kendisi kurmaktadır (Ünal, 2011: 141-142). Bu süreçte bireyselleşen ve öznelleşen birey, ruhsal, dinsel ve toplumsal bakımdan birtakım alternatiflere yönelerek anlam arayışına türlü cevaplar bulmaya çalışmaktadır.

Modernleşme sürecinde hızlanan anlam arayışı dinin toplumsal hayatta gerileyeceğine ve toplumsal işlevlerinin zayıflayacağına ilişkin iddialardan beslenmektedir. $\mathrm{Bu}$ durum klasik sekülerleşme teorisinin temel yaklaşımını oluşturmaktadır (Çapcioğlu, 2017b: 141-152). Sekülerleşme teorisinin söz konusu iddiası, P. L. Berger gibi 1lımlı sekülerleşme (Furseth ve Repstad, 2011: 157) taraftarlarınca (dünyanın kutsaldan uzaklaşmasının aksine) gündelik hayatta dinin yeniden aktifleşmesi ve 1960'lardan sonra yükselişe geçmesi şeklinde gerçekleşmiştir. Modern dünyadan el etek çekmesi beklenen dinin çoğulcu bir yapıya bürünerek varlığını devam ettirdiği görülmektedir (Bahadur ve Çapcıŏlu, 2021: 13). Modern dünyada o; görünmeyen din (Luckmann, 2016), ait olmadan inanma (Davie, 1994; 2005: 204) kişiye özgü din formlart (Wuthnow, 2012) gibi kavramsallaştırmalarla gündeme gelmiş ve yeniden mevcudiyeti söz konusu olmuştur (Gürbüz, 2020: 26). Touraine'in $(2000,339)$ Modernliğin Eleştirisi'nde belirttiği gibi din; modernliğin kriziyle anlamını kaybeden dünyayı yeniden şekillendirmektedir. Zira bu süreçte parçalanmış ancak bileşenleri yok olmamıştır (Gürbüz, 2021: 23). Sonuçta; kaybedilen anlam arayışı, dinsel yükseliş, kutsalın geri dönüşü, dinsel köktencilik ve çoğulculuk gibi yeni kavramsallaştırmalarla YÇA’nın ortaya çıkışına zemin hazırlamıştır.

Modern dönemdeki değişimlerle kurumsal dinlerin zayıflaması bireyin yeni kutsallık tarzlarını keşfetmesini sağlamıştır. Aşırı rasyonelleşme ile birlikte maneviyattan uzak yaşam formlarının yaygınlaşması, anlam kaybına ve maneviyat açlığının yeniden nüksetmesine yol açmışır. Bu durum bireyselleşme, öznelleşme ve ontolojik güvensizlik bağlamında mistik ve büyüsel niteliklere sahip yeni dini akımların ortaya çıkışına zemin oluşturarak (Arslan, 2006: 9) dini çoğulculuğa yönelik vurguyu güçlendirmiştir (Arslan, 2015: 59-60).

YÇA'nın yükselişi, kutsal bağlllıkların modernliğin tehdidine maruz kalmasıyla birlikte görünürlük kazanmıştır. YÇA, metafizik âlemle bağı zayıflayan 
modern insana kaybettiği anlamı yeniden sunmayı vadetmektedir (Köse, 2019, 18-9). $\mathrm{Bu}$ süreçte artan çeşitlilik ve çoğulculuk nedeniyle artık din, seçimi yapılabilen bir olgu haline gelmektedir (Arslan, 2015: 61). Bireyler sekülerleşen hayatın derin boşluklarını doldurmak ve belirsizliklerinden kurtulmak için yeniden kutsala sığınmakta ve yeni çağ akımlarına katılmaktadır. Bu durum, dinin oryantal uyanışı, yeniden kuruluşu ve yeni dini bilinçlilik gibi nitelemelere konu olmaktadır. 1960’lı yıllardan itibaren ekonomik olarak gelişmiş ülkelerdeki söz konusu akımlar; evanjelizm, fundamentalizm, mistik, paranormal inanç ve uygulamalar gibi dinimanevi kategoriler kapsamında incelenmektedir (Arslan, 2006: 11)

$\mathrm{Bu}$ yeni dönemde YÇA ya da paranormal inançlar, kişinin manevi/dini dünyasına yeni anlam kodları getirmiş, gelinen noktada kutsala dönüşten ve kutsalın patlamasından bahsedilir olmuştur. Özellikle mistik, ezoterik ve paranormal inançların son dönemde yaygınlaşması; paranormalizm denilen küresel bir fenomen olarak insanların ilgi alanına girmiş ve manevi/dini hayatın henüz yeterince fark edilemeyen aysbergine dönüşmüştür (Arslan, 2015: 55-56). Sekülerleşme sürecinde kurumsallaşmış dinlerin gerilemesinin paranormal inançlarda meydana getirdiği artış, parapsikoloji gibi yeni çağ (new age) yarı (quasi) sahte (pseduo) bilimsel yaklaşımları aracılığıyla yeni inanış biçimlerini ortaya çıkarmıştır (Parladır ve Özkan, 2015: 175).

Din sosyoloğu James Beckford, yeni inanış biçimlerine birinci kategoride Asya Felsefi Gelenekleri (Unification Church, ISCKON, Divine Light Mission, Eckankar, Rajneshh Foundation), ikinci kategoride Amerikan Pozitif Düşünce Geleneği, zihin kürü, hümanistik ve geştalt psikolojisi (scientology gibi), üçüncü kategoride ezoterik astroloji sistemleri, okült, büyücülük, sufizm ve cadılık; son kategoride ise Evanjelik Hristiyanlığın ortaya çıkardığı mesihçi toplulukları dahil etmektedir. YÇA'lar, Bekford'un üçüncü kategorisinde yer almaktadır (Beckford, 1987: 391).

YÇA, sekülerleşen dini yapıların dikkat çekici bir tezahürüdür. Çünkü bu süreçte din bireysel bir seçim meselesi haline gelir ve kendisini dini kurumlardan ayırır. Dahası 'gerçek din' olarak kabul edilen olgu, YÇA ile pek de uyumlu değildir. Burada YÇA, diğer birçok konuda olduğu gibi, kendini dini aydınlanmanın karakteristik mirasçısı görmektedir (Hanegraff, 1999: 153). YÇA ${ }^{1}$ modernitenin krizi

${ }^{1}$ YÇA (New Age) kapsamındaki inanç ve uygulamaların ortaya çıkışı 1900'lü yıllara dayandırılsa da, akademik çevrelerin dikkatini çekmesi 1950'li yıllardan sonra olmuştur. Wouter J. Hanegraff UFO kültüne inanan gruplara 'proto-new age' tanımlaması yapmaktadır. New age temsilcilerinden biri olan David Spangler, dönüştürücü ve yaratıcı ruhu ifade etmeye yönelik bir alan olarak nitelemektedir.

Turkish Academic Research Review - Türk Akademik Araştırmalar Dergisi 
ile insanın hayatını anlamlandırma ve kaygılarını giderme konusunda yaşadığı varoluşsal krizlerin neticesinde aşırı rasyonelleşmenin bir ürünü olarak ortaya çıkmıştır. Hızlı toplumsal değişmenin beraberinde getirdiği sorunlar YÇA'nın meşruiyet zemini bulmasını sağlamıştır. Bununla birlikte modernliğin krizinin yol açtığı bu durum, postmodern bir alandan da beslenmekte ve böylece mileneryalist görüşleri yaygınlaştırmaktadır. Bu nedenle yeni çağ akımlarında yeniden doğuşa ve yenilenmeye ilişkin inanışlara vurgu yapılmaktadır (Arslan, 2006: 19).

Yeni çağ akımlarının kökleri genellikle 19. yüzyıl sonu ezoterik kültüre, bazılarınınki ise 20. yüzyılda ortaya çıkan insan potansiyellerini geliştirme akımlarına dayanmaktadır. YÇA, gizli-doğaüstü güçlere yönelik inanışlar (okültizm), insan potansiyellerini geliştirme akımları (human potential movements), neo-paganizm, büyücülük (witcraft), şamanizm ve satanizm gibi akımlara kadar uzanan mistik ve ezoterik inançları kapsamaktadır. Manevi uyanış, keşif, kozmik bilinçlilik ve doğanın bütünlüğüne inanma (holism) gibi başlıklar da bu kapsamda değerlendirilmektedir (Hanegraff, 1996: 522).

Seküler trendlerin etkisiyle küreselleşen YÇA'lar (Pearson, 2002: 187-8) Batı okültizmi ve Doğu mistisizmden esinlenen çeşitli inançların oluşturduğu bir mozaik görünüme sahiptir (Biçer, 2006: 28). YÇA'lar, fenomenolojik açıdan incelendiğinde; insanı merkeze alan, Tanrı'yı evrendeki kozmik enerjinin kaynağı olarak değerlendiren ve sundukları kurtuluş reçetesi ile içsel uyanışı sembolize eden mistik oluşumlardır. Hanegraff, YÇA'y1; tinsel bir alt kültür olarak tanımlamakta ve modern toplumlarda dini karakterli bir inanış hareketi olarak ortaya çıktıklarını belirtmektedir (Pınarbaşı, 2021: 55). YÇA'lar, bireyin kendisini gerçekleştirmeye yönelik arayışını desteklemesi ile tinsellik, maneviyat ve inanç gibi kavramlarla ilişkilendirilmelerinden dolayı "din” kategorisine dâhil edilmektedir (Mirza, 2018, 19). Diğer taraftan seküler ve ezoterik bir dil kullandıkları için kendilik bilinci ve farkındalığın geliştiği topluluklar olarak adlandırılmaktadır (Hanegraff, 1996: 522).

YÇA'lar, eklektik bir yapıya sahip olmalarından dolayı dini bir akımdan ziyade bir düşünce sistemi, çeşitli dinlerden derlenen bir felsefe; astroloji, rüya, bitkisel tedavi, Feng Sui, mistisizm gibi çeşitli alanları kullanan bir ticari organizasyon; mistik tedavi tekniklerine başvuran bir kült hareketi olarak da tanımlanmaktadır. YÇA adı altında toplanan maneviyatçı gruplar, yeni ruhsal

1970'lerin başlarında daha fazla görünürlük kazanan YÇA (New Age Movement), spiritüalizm, teosofi ve yeni düşünce gibi mistik deneyimleri vurgulayan doğu dinlerinin öğretilerine dayanan bir yapılanma olarak tanımlanmaktadır (Pınarbaşı, 2021, 57). 
eğilimler olarak rasyonelliğe, geleneksel dine ve teknolojinin yıkıcı etkilerine holistik bir yaklaşım sergilemektedir. İçlerindeki pek çok inanç ve uygulama ile çeşitli muğlaklıklar kadar popüler alternatif kutsallıkları da bünyelerinde barındırmaktadır (Aydın, 2015: 43-4). Bu nedenle YÇA'lar; 'Batı ezoterizmi' (Hanegraaff, 1996), 'çağdaş alternatif dinler' (Hunt, 2003), 'Protestan halk dini' (Clark, 1982; Cohn, 1994), 'geleneksel Hindu uygulamalar' (Fuller 1992; Heelas ve Woodhead, 2005: 301), 'statik bir organizasyon' (Houtman ve Mascini, 2002: 458), 'kendin yap dini' (Baerveldt), 'seç ve karıştır dini' (Hamilton), 'alakart tüketim dini' (Possomai), 'spiritüel market' (Lyon) gibi nitelemelerle de anılmaktadır (Doğan, 2020: 29). Çok geniş yelpazede inanç ve deneyimlere yer veren bir hareket olarak YÇA; bir yandan reenkarnasyon, astroloji, teosofi, paganizm, büyücülük, astrofizik, parapsikoloji, eft, reiki, kişisel gelişim, beden şifası gibi mistik öğelere sahipken diğer yandan paranormalizm, alternatif tıp, şifacılık ve UFO'lojiyi içermektedir (Arslan, 2006: 1516). Ayrıca yüksek benlikle iletişim (kanal olma, rüyalar, hipnoz, meditasyon), kişisel gelişim ve insani potansiyelin açığa çıkması (psikosentez, nlp, astral seyahat), şifa çalışmaları (reiki, biyoenerji, zikir, nefes çalışmaları, yoga), kehanet (astroloji, tarot, numeroloji) gibi uygulamaları da kapsamaktadır (Başkaya, 2006: 104). Nihayet YÇA okültist ve spiritüalist oluşumlar, popüler psikoloji, meditasyon ve uzak doğu mistik uygulamaları, astroloji gibi yeni inanışları müşterilerine servis etmiş olmaktadır (Ünal, 2011: 215).

YÇA modern hayatın kargaşası karşısında anlam arayan bireyleri manevi yönden arındırmayı, böylece mutluluğa, bolluğa, berekete ve şifaya ulaştırmayı vadetmesi nedeniyle yoğun talep görmektedir. Çünkü bireyin anlam arayışının odağında inanma duygusu yer almaktadır (Çapcıoğlu-Yürük, 2010: 25). İnsanın anlam arayışında varoluşun gizemi, bireysel yaşantılar ve benlik algısı gibi konular kutsal ile ilişkiyi belirleyen en temel başlıklardır. Böylece yeni çağ akımları bireyselleşme sürecinde maneviyat temelli bir varoluş felsefesinin ortaya çıkışına katkıda bulunmaktadır. Doğu ve Batı gizemcilerinin çeşitli öğretilerinin yanında sekülerleşme ve tekno-bilişimsel değerlerin bireylerin gündelik yaşantılarına nüfuz etmesi, kutsala ilişkin yeni söylemlerle kişisel gelişim ve akıl yürütmelerine uygun brikolaj inançların gelişimini gün geçtikçe daha da popüler hale getirmektedir.

\section{Modern Şifacılık Yönelimleri}

Modern dünyanın krizi ve anlam arayışının ürünü olan YÇA ya da paranormal inançlar, postmodern dönemde yükselişe geçmiş ve bireyin manevi ihtiyaçlarını karşılama alanı olmuştur (Tosun ve Cesur, 2018: 171-2). YÇA'nın etkisiyle son dönemlerde yaygınlaşan şifacıllk yönelimleri maddi-manevi huzursuzluk, krizler ve

Turkish Academic Research Review - Türk Akademik Araştırmalar Dergisi 
değersizlik duygusu gibi durumlarla sıkça karşılaşan modern insanın problemlerine alternatif çözümler sunmaktadır. YÇA’lar modern dönemde şifa anlayışını geçmişteki inançlardan farklı seküler bir perspektifte inşa etmektedir. Böylece modern trendler dünün şifacılarını eft, bilinçaltı ve kişisel gelişim gibi yeni kalıplara büründürerek yeni bir şifacılık türü geliştirmektedir (Arıcı, 2021a: 239-241). İnsanların manevi beklentilerini karşılamayı amaçlayan bu yeni inanış biçimleri, şifa kültleri ve gruplarından oluşmaktadır.

Tarih boyunca insanın muhtelif hastalıklar karşısında şifa arayışında olduğu bilinmektedir. Bu arayışta "şifa" kavramına yüklenen anlamın kısaca açıklanması gerekir. 'İyi etmek, sağlığına kavuşturmak' anlamlarına gelen 'şifa', Batı dillerinde 'heal' sözcüğü ile ifade edilir ve 'kişinin sağlığına geri döndürülerek manevi bütünlüğüne yeniden kavuşturulmasını' tanımlar (Arıcı, 2021b: 294). 'Şifa' uygulamaları, hastalığın giderilmesinde öncelikle ruhun tedavi edilmesini hedeflediği için hastanın sadece bedenini değil, ruhunu da iyileştirmeyi amaçlamaktadır (Kaplan, 2015: 189). Batı ülkelerinden sentezlenerek modern bir şekle büründürülen 'şifacılık' uygulamaları, İslam dünyasında da yeni bir piyasa oluşturmaktadır (Aslan, 2016: 314; Aysoy, 2013). Esasen Kur'an-1 Kerim'de Allah'ın isimlerinden biri olan 'eş-Şafi', şifayı ve devayı verenin, kişinin manevi sıkıntılarını giderenin Allah olduğu inancını dile getirmektedir. Kur'an'da altı yerde ${ }^{2}$ geçen 'şifa' sözcüğü, dini-manevi ve bedensel olarak hastalıkların ilacıdır (Erten, 2020: 403). Hristiyan teolojisinde de şifayı Tanrı'dan bekleyip Tanrı'dan bulma anlayışı vardır (Arıcı, 2021b: 295). Hz. İsa, 'şifa mucizesi' ile kendisine inanan herkesin hastalıklarını iyileştirerek şifa bulmasını sağlamıştır. Hristiyanlıkta çeşitli şekillerde devam eden şifa uygulamalarının en bilinen örneği vaftizdir (Erten, 2020: 394). Budizm ve Hinduizm'de ise 'şifa'nın; panteizm, spiritüalizm ve kozmolojiden beslenen yoga ve meditasyon ile geleceğine dair yaygın bir inanış vardır. Dolayısıyla birçok inanışta 'şifa' maddi-manevi iyileşmeyi ifade etmektedir. Bu çerçevede YÇA'nın kullandığı şifa türü olarak enerji şifacılığına (energy healers) değinmek gerekir.

YÇA başlığı altında Doğu'nun mistik anlayışıyla harmanlanan (Arslan, 2006: 13) yeni inançlar modern şifacıllk yönelimleri ile enerji şifacıllı̆ı (energy healers) adı altında yeni gruplar oluşmaktadır. Günümüzde modern şifacılık yönelimlerinden enerji şifacılığı manevi şifalanma uygulamalarıyla yaygınlaşmaktadır. Enerji şifacıllı̆ı vücuttaki enerjiyi harekete geçirmeyi amaçlayan yöntemlere dayanmaktadır. Buna

2 Bkz. et-Tevbe 9/14; Yunus 10/57; el-İsra 17/82; el-Fussilet 41/44; en-Nahl 16/69; eş-Şuarâ 26/80. 
göre her insanın bir enerjisi vardır ve bu enerji kendi kendine harekete geçebilmektedir. $^{3} \mathrm{Bu}$ yaklaşım şifacının konumunu geleneksel kültürden farklılaştırmaktadır. Burada şifacı, manevi bir otorite değil, uyguladığı yöntem ve tekniklerle kişinin enerjisini harekete geçirerek rahatsızlığının çözümüne katkıda bulunan kişidir (Healas, 1999: 83).

YÇA inançları arasında kabul edilen enerji şifacılığı her kesimden insana hitap etmekte ve kişisel, fizyolojik tüm problemlere çözüm sunmayı amaçlamaktadır. Enerji ile şifalanma; insanın fiziksel bedeni dışında; eterik, astral, mantral ve spiritüel bedenlere sahip olması, enerjinin çakralardan bedene akması, kişinin kendini bedensel ve ruhsal açıdan iyi hissetmesi olarak anlaşılmaktadır (Aubyn, 1998: 50). Şifa verme ve şifalanma, bedenin süptil bir enerjiye sahip olduğuna ve evrenin bahşettiği bu enerjinin ruhsal boyutta kullanılması düşüncesine dayanmaktadır (Erdoğan ve Çınar, 2011: 87). Enerji ile şifalanma tekniklerindeki şifa kavramı kişinin kendine karşı dürüst olması, önyargılarından kurtulması, 'kendisi’ ve gerçek bir ‘ben’ olmasını ifade etmektedir. Enerji ile şifalanma tekniğinde enerji kanalının temiz olmasının yanı sıra doğru zamanda ve yerde kullanılmasının kişiyi rahatlattığı, günlük ve geçmiş problemlerindeki blokajı engellediği ve doğru şifa alımı ile sonuçlandığı belirtilmektedir (Wynee, 2017: 22).

Bedendeki hastalıkların kişinin kendi kendine şifalanması ile ortadan kalkacağı inanc1, modern şifacılıkta birçok teknik ve uygulama ile gerçekleştirilmektedir (Başkaya, 2006: 110). Enerji şifacılığı uygulamaları farklı inançlardan derlenen verilerle inşa edilmekte ve ülkemizde reiki, meditasyon, nefes egzersizleri, aura temizliği, nlp, biyoenerji gibi birtakım kişisel gelişim ve şifacı gruplar tarafından tercih edilen uygulamalarla günden güne artmaktadır. Kişinin geçmişindeki olumsuz bilinçaltı girdilerinin temizlenmesi (Günay, 2011: 85), farkındalık geliştirme, bolluk bereket atölyeleri ile şifalandırma çalışmaları da yapılmaktadır.

Enerji ile şifalanma teknikleri; geçmişte bilinçaltına itilen olumsuzlukları giderme, bolluk ve bereket taleplerine yönelik seanslar düzenleme gibi uygulamalarla bireylere sunulmaktadır. Bireyler, medya ve sosyal medya araçlarının sağladığı kolaylıklarla şifa gruplarına daha fazla yönelim göstermektedir. Böylece kutsalın yeniden tezahürü adı altında oluşturulan bu grupların şifa kavramının boyutunu değiştirerek yalnızlaşan bireye toplumsallığın varlığını hissettirdiği anlaşılmaktadır.

3 “Şifa Enerjisi”. (Erişim 14 Eylül 2021). https://www.okumanya.com/sifa-enerjisinedir-5-sifa-enerjisi-teknigi.html.

Turkish Academic Research Review - Türk Akademik Araştırmalar Dergisi 
Modern dünyada kendini manevi açıdan boşlukta ve yalnız hisseden bireye psikolojik terapi teknikleri ile yaklaşılmakta ve bu bağlamda gelişen enerji şifacıllğ̆ uygulamaları bireyin inancına göre uyarlanmış hizmetleriyle gittikçe popülerlik kazanmaktadır (Arıc1, 2021b: 320). Eski Hint ve Uzak Doğu dinleri ile mistik felsefelerinden derlenen söylemleriyle enerji şifacılı̆̆ı uygulamalarının hedef kitlesi, dini hassasiyeti zayıf olan ve anlam arayan kişilerdir. Bu uygulamalar hemen her kesimden insana sosyal medya aracılığı ile kolaylıkla ulaşabilmektedir. Ülkemizde enerji şifacılığı uygulamalarına ilgi her geçen gün artmaktadır (Arıcı, 2021b: 239). Bu kapsamdaki uygulamalar arasında ülkemizde ve dünyada ilk olarak Ferhan Sezer tarafından hayata geçirilen, cennet frekansında yüzyüze ve çevrimiçi eğitimler verildiği iddia edilen yaşam çiçeği (flower of life) ile bereket ve şifa tekniği popüler hale gelmiştir. Ferhan Sezer'in tekniği olan yaşam çiçeği, varoluşun özünü ifade eden, bolluk, bereket, sevgi ve evrenle bütünleşme enerjilerini taşıyan sembol olarak ifade edilmektedir. ${ }^{4}$

Yüzyıllardır insanlık için özel anlamlar taşıyan kutsal geometri adıyla anılan on dokuz çemberli bu figür, kadim imge ve sonsuz bolluğun sembolü olarak kabul edilmektedir (Albayrak, 2016: 274). Çiçeğe benzerliğinin yanı sıra meyve ağacını da temsil eden sembolün, Mimar Sinan'ın eserlerinde, Hacı Bektaş-1 Veli Türbesi'nde ve Pompei şehrinde de kullanıldığı söylenmektedir. Ayrıca yaşam çiçeğine atfedilen kutsallık içinde bulunan ilk yedi çember dünyanın yedi günde yaratıldığı rivayeti ile de bağdaştırılmaktadır. Özellikle Platon'un beş özel cismi ile Metatron'un küpünü ve Vesica Pisces sembollerini içermektedir. Her şeyi oluşturan kutsal oranların ifadesi olan bu sembol semavi dinlerde yaratılışın mükemmelliğini, Budizm'de Buddha'nın aydınlanmaya ulaştı̆ı̆ yeri temsil etmektedir. Evrenin yaratılışını ve bolluk enerjisini aktaran en güçlü sembol olduğu düşünülmekte; taşındığında ve kendisiyle meditasyon yapıldığında, maddi-manevi zenginleşmeye ve bolluk-berekete vesile olacağına inanılmaktadır. Bu sembolün, ayrıca içimizdeki öz cevher ile irtibatın sürekliliğini sağlayan imge olduğu kabul edilmektedir. ${ }^{5}$

\footnotetext{
4 "Yaşam Çiçeği”. (Erişim 11 Eylül 2021). https://www.yasamcicegisifa.com/, http://ferhansezer.com/

5 "Yaşam Çiçeği".

https://tr.wikipedia.org/wiki/Ya\%C5\%9Fam_\%C3\%87i\%C3\%A7e\%C4\%9Fi, https://altinbaslife.com/mucevher/yasam-ciceginin-bilinmeyensirri/https://ql.com.tr/articles/kutsal-geometri-yasamcicegi,https://blog.mitr.com.tr/yasam-cicegi-sembolunu-nedenkullanmalisiniz,http://www.dinvemitoloji.com/2018/05/yasam-cicegi.html. (Erişim 11 Eylül 2021).
} 
Yaşam Çiçeği ile Şifa Tekniği Ferhan Sezer tarafından beyaz, mavi, beyaz zambak, sarızambak, altın, mor, akustik pembe, akustik turuncu, lotus çiçeği gibi şifa kodlamalı sözler ile bedensel farkındalık, çakra açılımı ve kendini bulma gibi seçenekleriyle arayış içinde olan bireylere sunulmaktadır. Yaşam çiçeği sembollü ürünler ile şifalanma çalışmaları ve bu çalışmalarda tekrarlanan şifalı sözlere gerçekten inanan kişiler, enerji şifacılığından yararlanabilmektedir. Sembol ve dil üzerinden gerçekleşen şifalanma, frekansın değişeceği, yaşamdan zevk alma, arınma, günlük sıkıntılardan rahatlamaya yönelik dua paketi olarak sunulmaktadır. Ferhan Sezer Yaşam Çiçeği ile Şifa Tekniği’ni beden şifası, yaşamda enerji kullanımı, su şifası gibi daha birçok teknikle insanlığın hizmetine sunduğunu belirtmektedir.

Yaşam Çiçeği ile Şifa Tekniği örneğinde YÇA, sembol ve imalara dayalı bir dil geliştirmekte, modern dünyada inanç zemininin kayganlaşmasıyla oluşan manevi boşluğu doldurmaya çalışmaktadır. $\mathrm{Bu}$ boşluğum, semboller üzerinden anlam arayışının giderilmesi, enerjinin doğru akması ve gerçekleşmesi için uygulanan seanslar ile doldurulması amaçlanmaktadır. Bireylere kaliteli yaşam sunma, sıkıntı ve problemlerini giderme vaadiyle beden, zihin ve ruh dengesini korumaya yönelik enerji terapi ve uygulamaları ücretli ve ücretsiz olarak sunulmaktadır. Ülkemizde de kişisel gelişim, yoga ve meditasyon gibi enerji yoluyla şifa uygulamaları gittikçe popülerlik kazanmakta ve katılımcıların ilgisini çekmektedir. Bu ilgide etken rolü yeni medya platformları oynamakta ve söz konusu çevrimiçi topluluklara katılım sosyal medya hesapları aracılığıyla gerçekleşmektedir.

\section{Altın Çağ Şifa Teknikleri}

Altın ça $\breve{g}^{6}$ olarak adlandırılan 21. yüzyıl bilgelik çağında bireylerin ihtiyaç ve taleplerinin farklılaşacağı, arayış, anlam, içsel dünyada özgürleşme ve bireyselleşmenin yaşanacağı iddia edilmektedir. Son zamanlarda geleneksel din anlayışının dışında farklı din ve inançlara, mistik, ruhçu ve paranormal olgulara yönelimin artması, bu iddiaları destekleyen göstergeler arasındadır (Günay, 2003: 2; Arslan, 2006: 21). Ülkemizde bu tür uygulamaların ortaya çıkış nedenleri arasında aşağıdaki hususlar sayılmaktadır: Modernleşme, bireyselleşme, yabancılaşma, insan doğasında bulunan gizemli olana merak, apolitikleşme, küreselleşme, aşırı dünyevileşme, rasyonalizasyon, çözülme ve İslam'a güvensizlik, geleneksel İslami söylemin güncellikten uzak oluşu, kişilerarası iletişim ihtiyacı, psikolojik arayış ve hoşgörü (Pınarbaşı, 2021: 90-94). Dinsel yükseliş, kutsalın geri dönüşü, dinsel

${ }^{6}$ Türk mitolojisinde, halk inancında ve toplumsal felsefe de mükemmel dünya halidir. Wikipedia. "Altınçağ”. (Erişim 21 Eylül 2021).

https://tr.wikipedia.org/wiki/Alt $\% \mathrm{C} 4 \% \mathrm{~B} 1 \mathrm{n} \% \mathrm{C} 3 \% \mathrm{~A} 7 \mathrm{a} \% \mathrm{C} 4 \% 9 \mathrm{~F}$

Turkish Academic Research Review - Türk Akademik Araştırmalar Dergisi 
köktencilik ve çoğulculuk gibi yeni kavramsallaştırmalar ile bu akımların ortaya çıkışı sadece fiziksel dünyada değil, dijital platformlarda da kendini göstermektedir. Dine ve maneviyata yönelik ilgi, dijital platformlarda faaliyet gösteren kişi ve gruplar aracılığıyla sosyal ağlarda taraftar bulmaya devam etmektedir (Bahadur ve Çapcıoğlu, 2021: 13). Modern dünyada mistik arayışlar, bireyselleştirilmiş biçimleriyle tezahür etmekte ve bu anlamda insan merkezli bu yaklaşımlar terapi kültleri, seküler ruhsalıklar, alternatif terapiler ve paranormal inançlar olarak, yeni kitle iletişim araçlarıyla toplumun gündemine taşınmaktadır (Arslan, 2006: 16).

Dinlerin dijital platformlarda temsiline ve interaktifliğine imkân sağlayan yeni medya ortamları geleneksel medyadan ayrılmaktadır. Yeni medyanın ortaya çıkışıyla birlikte iletişim süreci ve biçimi köklü bir biçimde değişmiştir. Bu durum yeni bir din anlayışını, sanal din ya da dijital din kavramını gündeme getirmiştir. Günümüz iletişim teknolojilerinin toplumsal yaşama egemen olduğu çağ olarak tanımlanan dijital çağ, toplumsal hayatın kültürel, iktisadi ve dini boyutlarını da içine alarak bir dijitalleşme sürecini meydana getirmiştir. 2020 y1lının başlarından itibaren tüm dünyayı etkisi altına alan Covid-19 salgını bu süreci daha da hızlandırmıştır (Çapcıoğlu ve Kaya, 2021). Dijitalleşmenin en önemli ayağını oluşturan yeni medya; din, dindarlık ve maneviyatın boyut ve içeriklerinde değişimlere neden olmuştur (Çapcioğlu ve Anık, 2021: 27-43; Çapcioğlu, 2020b). Toplumsal yaşam ile dijital dünya arasındaki geçişkenlik dinin de medya alanında varlığını sürdürmesine imkân sağlamıştır. Kurumsal etkinliği zayıflayan dinin alanı (geç modern dönemin paradoksal sonuçları çerçevesinde) bireyin ilgileriyle sınırlandırılmıştır. Bu sınırlılıklar nedeniyle fiziksel dünyanın imkânları ile özdeşleştirilen toplu ibadet ve dua gibi ritüeller sanal temsiller aracılığıyla dijital platformlara taşınmıştır (Narmanlığlu, 2015: 70; Haberli, 2019: 308). Bununla birlikte son yıllarda geleneksel dini inanç ve ritüellerin internet ortamındaki kullanımı tartışılmaktadır (Campbell, 2006: 4).

Modern insanın anlam arayışında en etkili araçların başında yeni medya platformları gelmektedir. Yeni medya, büyüsü bozulan dünyanın adeta yeniden büyülenmesi işlevini üstlenmektedir. Bu süreçte insanın anlam arayışında paranormal inançların işlevselliği artmaktadır (Arslan, 2015: 66). Paranormal inanç ve uygulamalar kutsalın yeni medyadaki üretimine ve yeni anlam arayışına alternatifler oluşturmaktadır. Söz konusu inanışlar yeni medya mecralarında kendilerine yer bularak mesajlarını geniş kitlelere ulaştırabilme firsatı yakalamakta ve böylece çeşitli 'dinsel/maneviyatçı' görünümlere sahip olabilmektedir (Gazneli ve Kılıç, 2020: 198; Karaarslan, 2015: 28-9). Günümüzde internet, manevi doyum amaçlı arayışların 
dijital ağlardaki temsiline aracılık eden önemli bir işlevi yerine getirmektedir. İnternette sesli, görüntülü ve multimedya iletişim imkânına kavuşan YÇA'lar, bireylerin ruhsal açlıklarını doyurmayı vadetmektedir (Vardi, 2015: 146). Dijital dünya ihtiyaca göre içerik düzenlemeleriyle arayış içindeki bireylere fiziksel temas olmaksızın tek bir tuş ile kolektifleşme imkânı sunmakta ve bu sayede her geçen gün daha çok tercih edilmektedir (Gazneli ve Kılıç, 2020: 123-5).

Yeni medya döneminde sesin ve görüntünün bir arada bulunması, iletilmesi, geleneksel medyanın bütün çeşitliliği ile web ortamına taşınması ve interaktif olması, dijital mecraları dini grupların da ilgisini çeken bir platforma dönüştürmüştür (Akgül, 2017: 204-6). Dünya çapında bir denetim mekanizması olarak internet, bireyleri gerçek ilişkiler dünyasından soyutlayarak sanal dünyaya özgü yeni yaşam ve ilişki biçimleri sunmaktadır. Bu yeni ortam, Facebook, Instagram, Twitter gibi sosyal ağlar sayesinde yersiz yurtsuzlaşmış bir arzu mekânına dönüşerek sanal sosyalleşme platformları oluşturmakta, gerçek dünyadan sanal dünyaya akışa sebep olmaktadır (Kara, 2017: 15-6). Modern çağda sosyal medya kendini kanıtlamanın en uygun yoludur. Birçok insan sosyal medya aracıllğıyla yeteneklerini ortaya çıkartabilmekte, hem şahsi paylaşım hem de başkalarının paylaştığı fotoğraf ve videolarla dünyayı gözlemleme imkânı bulabilmektedir. Bununla birlikte, son yıllarda internet giderek artan bir şsekilde bireylerin günlük yaşamlarına gömülmüş, sosyal hayatlarını kolaylaştırmış, çevrimdışı ve çevrimiçi dini davranışlar ve inançlar arasındaki bağlantının araştııılması yönünde gelişmelere kaynaklık etmiştir (Campbell ve Lövheim, 2011: 1083).

Yeni çağ inanışları esnek bir modelde hem çevrimiçi hem de çevrimdışı alanlarda (siber uzamda) faaliyetlerini sürdürmektedir. Çevrimiçi topluluklar dini ve manevi dünya olarak kurgulanmıştır. Dijital alanda kutsal olanın çevrimiçi hale gelmesi, bu mecraları firsat gören maskeli bilginlere yeni ruhsal arayıcı (Dawson ve Hennebry, 2003: 270) tanımlaması yapmaktadır. Böylece çevrimiçi uzam şifa eğilimli hipnoz, biyoenerji, akapuntur, homoopati (Aydın, 2015: 58; Sevgi, 2011: 163; Dereli, 2020: 86; Dereli, 2021: 173), eft, reiki, bioenerji, yaşam çiçeği ile beden şifası gibi şifacı uygulamalar ile sağlıklı yaşam, huzur, bedensel memnuniyet gibi vaatler sunan grupların çoğalmasını ve takip edilmesini kolaylaştırmaktadır.

Dinin çevrimdışı dünyadan çevrimiçi uzama intikal ederek dijitalleşmesi, genellikle ritüeller boyutunda görünürlük kazanmaktadır. Çevrimiçi ritüel; geleneksel dini pratiklerin siber uzamda kendisine yer bulmasını ifade eder. Kiliseye mail atma, çevrimiçi dua (Dereli, 2020: 96-7), sanal Kâbe ziyareti, siber mabet (Brasher, 2001)

Turkish Academic Research Review - Türk Akademik Araştırmalar Dergisi 
gibi inanç, pratik ve tecrübeler için dijital uzam, spiritüel aktarma merkezi (Campbell, 2012: 14) olarak kullanılmaktadır. Çevrimiçi ortamlar aracılığıyla sağlanan iletişim sosyal medya dili ile belirtmek gerekirse takipçi aboneleriyle bir topluluk oluşturma (Dereli, 2020: 281), geribildirim (feedback) alma, dm (mesaj) bölümünden iletişime geçme, canlı yayın ile etkileşimde kalma gibi imkânları sunmaktadır. Sosyal medya kendini kanıtlamanın en uygun yoludur ve herkes sosyal medya aracılığıyla tüm özelliklerini ortaya çıkartabilmektedir. Birçok insan fotoğraflarını ve mesajlarını paylaşarak dünyayı izlemektedir (Cereci, 2020: 20). Kişisel yaşamlarına katkıda bulunacak dini bilgileri edinmek için sanal mecralara yönelen bireyler, çeşitli ritüellerin yanı sıra dini bilgilerini de çevrimiçi olarak geliştirmekte ve böylece bireysel manevi gelişimlerine yatırım yapma imkânı bulmaktadır (Campbell, 2012: 4). Yüzlerce çevrimiçi site ve ağ ile birlikte çevrimiçi birçok ibadet ve ritüel, siber mabetler ve siber kiliseler gibi uygulamalar sayesinde insan hayatına siber uzamın eklenmesiyle karşılıklı etkileşimin sağlanabileceği çevrimiçi ortamlara ve dijital topluluklara katılım firsatı sunmaktadır (Campbell, 2006: 5; Dereli, 2021: 171). Bu çerçevede bir YÇA örneği olarak çevrimiçi platform Instagramı kullanan 'Ferhan Sezer Altın Çağ Şifa Teknikleri' sayfası, biyoenerji, eft, altın çağ şifa teknikleri, bolluk-bereket, iyilik ve mutluluk, para okulu gibi şifa tekniklerine ilişkin eğitimler vermektedir. Platformun kurucusu, kendisini eğitimci yazar ve girişimci olarak tanıtan Ferhan Sezer $^{7}$ cennet gibi bir yaşamın mümkün olduğuna inanan ruhlara cennet frekansında çevrimiçi eğitim ve teknikler sunduğunu iddia etmektedir. Aynı zamanda yaşam çiçeği ile şifa, çiçek enerjileri ile şifa, kodlamalı şifa ürünleri gibi enerjisel şifa uygulamaları ile günlük yaşamda mutlu bir yaşamın mümkün olduğuna dair farkındalık oluşturmayı amaçlamaktadır.

Mersin'in Tarsus ilçesinde orta sınıf bir ailede dünyaya geldiğini söyleyen Ferhan Sezer, küçük yaşlarda varsıl ve yoksul aileler arasındaki farkın dikkatini çektiğini ve bunun çözüm bekleyen bir sorun olduğunu fark ettiğini belirtmektedir. Bu doğrultuda kendisine yüklediği misyonla; yüzde yüz ilahi sistemle bağlantıda kalarak kendi fani kimliklerimizi değil, Allah’ı yücelterek, insanoğlu için dünyada cenneti yaşamanın mümkün olduğunu söylemektedir. Kim olduğuna ilişkin sorulara kendisini 'Allah'ın memuru' olarak nitelendirerek cevap vermektedir. ${ }^{8}$

\footnotetext{
${ }^{7}$ Bolluk, bereket ve paraya dair kitapları bulunan Ferhan Sezer 7 yıldır birçok eğitim, seminer ve videolarla dünyada cennetin mümkün olduğuna dair bir farkındalık gerçekleştirdiğini iddia etmektedir. Bkz. Ferhan Sezer (Erişim 21 Eylül 2021), http://ferhansezer.com/ferhan-sezeri-taniyalim/

8 "Ferhan Sezer'i Tanıyalım". (Erişim 31 Ağustos 2021).

http://ferhansezer.com/ferhan-sezeri-taniyalim/
} 
Ferhan Sezer, FS Altın Çă̆ın Şifa Teknikleri 22 başlığıyla modül 1 şifanın gücü (heal power) ve modül 2 çiçeklerin gücü (flower power) adını verdiği şifa tekniğiyle eğitimler düzenlemektedir. Modül 1 şifanın gücü; ilahi boyutta renklerin kullanıldığı, enerjisel boyutta hızlı şifalanma ve biyoenerji ile alakalı temel bilgileri içeren bir tekniktir. Ferhan Sezer modül 2 çiçeklerin gücünde ise 2019 yılında yaşam çiçeği enerjisini ilk kez dünya ile buluşturduğunu ileri sürmektedir. Çiçeklerin gücü, yaşam çiçeğinin evrensel bir sembol olduğuna ve enerji verdiğine inanılan; zambak, lale, papatya gibi çiçek enerjileri ile şifalanmayı içeren bir eğitimdir. Aynı zamanda para ve bereketle ilgili FS Para Okulu 888 isimli finans eğitimi, çocuk enerjilerine özel FS Altın Çă̆ın Çocukları 33 sistemi ile de eğitimler verilmektedir. Ayrıca FS Beauty Wellness 77 ile gençlik ve güzellik enerjisinin aktifleşmesine ilişkin eğitimler sunulmakta ve bu yolla birçok cilt problemi olan hastanın şifa bulduğu belirtilmektedir. Bu eğitimlerdeki genel slogan 'dünyada cennete hoş geldiniz'dir. ${ }^{9}$

\section{Araştırmanın Bulguları}

Ferhan Sezer'in 'Ferhan Sezer Altın Çağın Şifa Teknikleri' ve 'FS Yaşam Çiçeği Şifası' adlı Instagram sayfalarındaki 548 gönderiden yaşam çiçeği ile şifalanma, para okulu, özel kodlamalı altın çağ takıları olarak üç kategoride belli başlı gönderiler incelendiğinde, çeşitli dinsel söylemler içerdiği görülmektedir. Bu kapsamda gönderilerin çoğu şifalı sözlere ve çalışmalara dayanmaktadır. Bu paylaşımlar; "dini ve fikhi bağlayıcılık", "göz merkezli dünya tasavvuru” ve "akışkan tüketim” olmak üzere üç ana başlıkta değerlendirilebilir.

\section{Dini ve Fıkhi Bağlayıcılık}

Sosyal medyanın akışkan doğasında kişinin nasıl yönlendirildiği, gündelik hayat ve çevrimiçi uzam niteliğindeki deneyimleri (Dereli, 2020: 227), bir sayfayı takip etme isteğinde neden tercih edildiği dinsel yönelimleri ile ilgilidir. Dini ve fikhi bağlayıcılık bakımından 'Ferhan Sezer Altın Çă̆ Şifa Teknikleri' sayfasındaki profil ve paylaşımların çevrimiçi dini/ritüeli temsil ettiği ve dijital uzamı aktif olarak kullandığı anlaşılmaktadır. Paylaşımlar sıkça tekrarlanan gönderi ve kilit konular kapsamında ele alınarak değerlendirilebilir.

'Ben, bedenim ve yaşamım meccanen şükür frekansındayım'. ${ }^{10} \mathrm{Bu}$ paylaşım FS Şifalı Sözler adı altında F.S AÇŞT 22 eğitim içeriğinden düzenlenmiştir. Bu ifade tekrar edildiğinde frekansınızın değiştiği ve yaşamdan zevk almaya başlayacağınız bir

${ }^{9}$ Ferhan Sezer. "Eğitim”. (Erişim 31 Ağustos 2021). http://ferhansezer.com/ferhansezeri-taniyalim/

${ }^{10}$ (Erişim 2 Ağustos 2021). https://www.Instagram.com/p/CSmfGNuDx7G/

Turkish Academic Research Review - Türk Akademik Araştırmalar Dergisi 
alana geçildiği belirtilmektedir. Burada vurgulanan 'meccanen' sözcüğü, eski Türkçe'de 'bedelsiz verme', TDK'de ise 'karşılıksız, parasız' olarak tanımlanmaktadır. ${ }^{11}$ Ferhan Sezer, Instagram hesabındaki bir gönderide şükretmeye çalışmanın ne kadar zorlama olduğunu fark ettiğinde bu şifalı sözün doğduğunu söylemekte ve 21. yüzyılda Altın Çağ'dan bir şeyler alabilmek için enerjetik bir formülün gerekliliğinden bahsetmektedir. Bu çağda sistemin şükür alanı açtığına; sonsuz ve sınırsız bir alanda şükredilecek şeylerin otomatik olarak verildiğine ve herhangi bir bedel ödemeden karşılıksız sunulduğuna dikkat çekmektedir. Bu şifalı sözü tekrarladığınızda şükür gerektiren güzelliklerin ayaklarınızın altına serileceğini iddia etmektedir. Gönderiye ilişkin takipçi yorumları incelendiğinde, takipçilerin olumlama frekansının yaşamlarına etki ettiğini belirterek bu güzel dua için teşekkürlerini ilettikleri görülmektedir.

Şükür kavramı, yapılan iyiliği bilmek ve yaymak, Allah'tan veya insanlardan gelen nimetlere minnettarlık duymak şeklinde tanımlanmaktadır. Meşhur mutasavvıf Kuşeyri’ye göre derin bir saygıyla nimet sahibinin iyiliğini anmak olarak tarif edilen şükür; Kur'an'1 Kerim'de (el-İsra, 17/19; el-İnsan, 76/22) ve hadislerde (Müsned, 258, 295, 303; Tirmizi 'Birr', 35) insanların hayırlı işlerinin karşıllğı, verdiği nimetten dolayı kulun Allah'a, Allah'ın kullarına karşılık vermesi olarak açıklanmaktadır (Çağrıc1, 2010: 259-261). Altın Çağ'da şükür bilincinin, maddenin enerji ve titreşimlerden meydana gelmesi gibi insanın da enerji ve titreşimlerle doğasını değiştirme, evrenden aldığ frekans ile bedenindeki enerjiyi kontrol edebilmesiyle oluştuğuna inanılmaktadır (Arıc1, 2021: 239). Ferhan Sezer'in de temsilciliğini yaptı̆̆ı yeni çağ akımlarında şükür, meditasyon frekansı ile bağlantı sonucunda enerjiden doğan şifalanma ile açıklanmaktadır. Buna göre hangi enerjide olursanız yaşamınız o enerji doğrultusunda şekillenir. Modern bireyin şükür ve şifa arayışının bu tarz çevrimiçi dini topluluklar aracılığıyla giderilmeye çalışıldığı anlaşılmaktadır. Çevrimiçi uzam yeni anlamların yüklendiği şifa sözcüğünü enerji kavramı ile birleştirerek insanların enerji ve maneviyat arasında bir bağ kurmalarına aracılık etmektedir (Doğan, 2020: 66).

Ferhan Sezer hesabından yapılan başka bir paylaşımda 'Alfa frekansindayım, cennet frekansındayım', 'Dünyada cenneti yaşıyorum', 'Yaşamımın altın çağındayım' ve 'Bugün cennetten bir güne uyanıyorum.' cümleleri 7-9-11 kez tekrar edildiğinde farklı bir frekansa geçildiği iddia edilmektedir. ${ }^{12}$ Ferhan Sezer, bu ifadeler sürekli

11 "Meccanen". (Erişim 1Eylül 2021). http://www.lugatim.com/s/meccane; TDK.

“Meccanen". (Erişim 1 Eylül 2021). https://sozluk.gov.tr/

${ }^{12}$ (Erişim 2 Ağustos 2021). https://www.Instagram.com/p/CLAZFuvl5v6/ 
tekrarlandığında cennet frekansına geçişin ve dünyada cenneti yaşamanın kesinlikle mümkün olduğuna dikkat çekmektedir. Ona göre evrende ne varsa bir frekans ve titreşim halindedir. Kutsallığın evrende ve evrendeki nesnelerde olduğu için kaybolan anlamın evrende aranması gerektiğini savunan yeni çağ akımları, bedendeki frekansın harekete geçirilmesi kapsamında Uzak Doğu ve pagan kültürden kavramlara atıfta bulunmaktadır. Söz konusu akımlar kendilerini bir dini hareket olarak görmedikleri ya da göstermedikleri için muhatapları da bu akımlara özgü ritüellerin sarmalına nasıl girdiklerinin farkına varamamaktadır. ${ }^{13}$

\section{Göz Merkezli Dünya Tasavvuru}

Sosyal medyada görsel içerikli paylaşımların yapıldığı en etkili mecra olan Instagramda, kullanıcıların özellikle görme duyusuna hitap edilmektedir (Dereli, 2020: 163). Görsel paylaşımlar hem dikkat çekmekte hem de sosyal ağın verdiği imkânlarla beğenilip kaydedilebilmektedir. Kaydedilen paylaşımlar bir dosya halinde yer aldığı için takip edilen içeriklere her an erişim imkânı bulunmaktadır. Dualar medya aracılığıyla paylaşı1ırken dini algı teknolojik düzlemde konumlanmaktadır (Çamdereli, 2018: 121). Dua ve yakarış medyatik bir dille çevrimiçi ritüele dönüşmektedir. İnternetin sunduğu imkânlarla kutsal mekân ziyareti, dua etme ve başka insanlara dua gönderme gibi ritüeller çevrimiçi ortamda gerçekleştirilmektedir (Dereli, 2020: 301; Wagner, 2012: 102-3). Çevrimiçi ortamda dini unsurların ilk oluşumu dua uygulamaları ile olmaktadır. Yeni çağ akımlarının kullandığı sosyal ağlarda fotoğraf ve video paylaşımı kullanıcıları etkilemekte ve bu paylaşımlarda kullanılan dil takipçi sayısının artmasına doğrudan katkıda bulunmaktadır. Ferhan Sezer'in kendine özgü tekniği olan yaşam çiceği ile şifalanma çalışmalarında da gün boyu tekrar edilmesi istenen şifalı sözler paylaşılmaktadır. Bu paylaşımlara göre zamanın ötesinde hızla şifalanmak yaşam çiçeği ile mümkündür. Instagram hesabında yayınlanan fotoğraf ve IGTV videolarının yanı sıra, yaşamçiçeği.com adlı internet sitesinde de yaşam çiçeğinin nasıl işlediği anlatılmaktadır.

Yaşam çiçeği uygulaması ile zamanın ötesinde şifa dağıttığını iddia eden Ferhan Sezer, Yaşam Çiçeği ile Bereket ve Şifa kitabından alıntılanan gönderide aşağıdaki şifalı sözlere yer vermektedir:

"Bu evrende hangi yaşam çiçeği formu olduğumu beyaz zambak çiçekleri ile fark ediyorum." "Tekrar et yaşamın değişsin. "14

${ }^{13}$ Lacivert. "New Age Kültleri'”. (Erişim 2 Eylül 2021). https://www.lacivertdergi.com/dosya/2020/11/20/new-age-kultleri

${ }^{14}$ (Erişim 2 Ağustos 2021). https://www.Instagram.com/p/CTFTJZKDleE/

Turkish Academic Research Review - Türk Akademik Araştırmalar Dergisi https://dergipark.org.tr/tr/pub/tarr 
“Kurban bilincinden Kur'an bilincine mavi yaşam çiçekleri eşliğinde geçiş yapıyorum. "'15

"Sarızambak enerjisiyle ferasetim artıyor ve yaşamım güzelleşiyor. "16

Para Seninle Konuşuyor başlıklı kitabından alıntılanan gönderide kitabın takipçilere hediye edildiği belirtilmektedir. Altın Çağ’da para ile ilgili klasik bakış açılarını unutturduğu söylenen bu kitaptan alıntılarla oluşturulan dua kartlarına yer verilmektedir. Bu bağlamda Kart 8 'deki alıntı dikkat çekmektedir:

Odaklan... (el-Ganiyyu el-Muğnii -808 adet)...

Şimdi karnına odaklanıp nefes al ve ver... Şimdi ne kadar paran varsa ona odaklan ve talep ettiğin kadar parayı hayal et ve ilahi enerjiden çek.

Ve tekrar et zihninde canlandırıp görerek, işiterek, inanarak ve hissederek...

Odak noktam bolluk ve şükür.

Bu sebepten hayatımda bunlar çoğalıyor..$^{17}$

Hayatındaki boşluğu anlamlı bir biçimde doldurabilmek için çevrimiçi uzamda arayış içinde olan birey, kutsal rehberlere, seküler ruhsallıklara ve faaliyetlere yönelmektedir. Çevrimiçi platformlarda faaliyet gösteren alternatif oluşumlar hediye paylaşımlarla takipçilerin dikkatini çekmekte ve takipçi sayılarını artırmaktadır. Bu paylaşımlarda bolluk ve bereket gibi manevi kavramlar üzerinden, bütünüyle sermaye odaklı seküler talepler ortaya konulmaktadır (Arıcı, 2021: 320). Alternatif oluşumlara katılan birey elindekine kanaat etmek yerine sürekli isteme odaklı meta-destek çalışmalarına yönelmektedir. Ferhan Sezer bolluk-bereket seansları, bu bağlamda düzenlenen çevrimiçi ritüellerdeki şifalı sözlerle, yeni bir adımla bereket açma garantisi vermektedir. Bireysel dindarlıkları ortaya çıkaran kurumsal dinin yerini doldurmaya çalışan (her ne kadar dini oluşum olduklarını kabul etmeseler de) alternatif oluşumlar (Varlık, 2019: 22), bireyleri modern şifacılık adı altında sosyal ağlarda faaliyette bulunan dini/manevi ya da kült benzeri gruplara dâhil etmektedir.

YÇA'larda dini ögeler yerini okültik ögelere bırakmakta, reenkarnasyon inancı, panteist tanrı anlayışı ve ruhlarla kurulan ilişkiler gibi çevrimiçi ritüellere sıkça rastlanmaktadır. Bireyselliği destekleyen unsurlarla sözde dini ancak gerçekte

15 (Erişim 14 Ağustos 2021). https://www.Instagram.com/p/CRisXk5rhBE/

16 (Erişim 14 Ağustos 2021). https://www.Instagram.com/p/CLtzF1SLDm5/

17 (Erişim 2 Eylül 2021). https://www.Instagram.com/p/CJ9g4smrizA/ 
dünyevi olan hayata ilişkin vaatler gerçekleştirilmeye çalışılmaktadır. Ayrıca tekrarlanan dua kartları ile yaşamın dengelendiği ve bir lütfa dönüştüğü iddia edilmektedir. Çevrimçi mesaj, ileti, fotoğraf ve video paylaşımlarına yapılan yorumlardan YÇA'ların medyatik görünümlü temsillerle çevrimiçi ritüellere aracılık ettiği ve dini olanı araçsallaştırıp dünyevi olanı meşrulaştıran bir muhtevaya sahip olduğu anlaşılmaktadır. Böylece çevrimiçi ortamda gerçekleştirilen ritüellerin çevrimdışı dünyaya aktarımı sağlanmaktadır.

\section{Akışkan Tüketim}

Yeni dini akımların sosyal medyadaki görünürlüğüne yönelik bir alternatif de tüketimdir. Sosyal medya ağlarıyla birlikte tüketimin işleyişi de değiştirmiştir. Özellikle Instagram kullanıcıları kendi hesaplarından tanıtımlar yapabilmektedir. Instagramda görsellik öne çıktığı için bir ürünün metinsel ve görsel paylaşımı arasındaki etki farklılığı açıkça görülmektedir (Dereli, 2020: 151-6). Bu bağlamda 'FS Yaşam Çiceği Şifası' sayfasında kişiye özel kodlamalı altın çağ takıları satışı yapılmaktadır. $\mathrm{Bu}$ sayfada satılan tüm ürünlerin şifa niteliğinde olduğu vurgulanmaktadır. Sayfadaki görseller arasında taç çakra, kalp çakra, lotus çiçeği, yaşam çiçeği kolyesi, yaşam çiçeği tablosu, yaşam çiçeği gümüş su çubuğu, bereket iğnesi gibi çeşitli mistik simge ve ögeler içeren ürünler bulunmaktadır. Ferhan Sezer, yaşam çiçeği enerjisini bir şifalanma tekniği haline getirerek şifa kapasitesi olan insanlığın hizmetine sunduğunu iddia etmektedir.

'FS Yaşam Çiçeği Şifası' adlı Instagram hesabındaki ürünler arasında yer alan yaşam çiçeği gümüş su çubuğu ve yaşam çiçeği amblemli cüzdanların yanı sıra, en dikkat çekici olanı 'meccanen şükür frekansı' yazılı yaşam çiçeği tablosudur:

'Meccanen şükür frekansindayım yaşam çiçeği el işlemeli tablo; ortamı rahatlatır, negatifi alır, mekânda bereketi yükseltir, rahat uyku enerjisi sağlar, gece gündüz kullanıma uygundur'. ${ }^{18}$

Tablonun bulunduğu ortamdaki negatif enerjiyi aldığı, kişiyi rahatlatıp sakinleştirdiği; bu nedenle meditasyon, dua, namaz gibi ruhsal çalışma ve ibadetlerden önce kısa bir süre seyredilmesinin zihni sakinleştirerek daha huzurlu bir ibadet imkanı sağladığı iddia edilmektedir:

${ }^{18}$ (Erişim: 5 Eylül 2021).https://www.Instagram.com/p/COBMWzUDFpZ/

Turkish Academic Research Review - Türk Akademik Araştırmalar Dergisi https://dergipark.org.tr/tr/pub/tarr 
'Gümüş su çubuğu ile sular canlanır, şifalanır. Kendiniz kodlayarak ailenizi şifalandırabilirsiniz ${ }^{19}$

Ferhan Sezer patentli, içerisinde kullanım kılavuzu ile gönderilen yaşam çiçeği gümüş su çubuğunun ise suları şifalandırdığı; ayrıca şifa ve bereketi almaya gönüllü olanlara ve bunu tekrar edenlere kapıların açılacağı ileri sürülmektedir:

'Problemlerin çözülmesine, yaşamınızın bereketli ve neşeli bir yer haline gelmesine katkıda bulunmayı hedefliyoruz'. ${ }^{20}$

Yaşam çiçeği amblemli mor, kırmızı renklerde satılan cüzdanların bolluk ve bereketi temsil ettiği ve cüzdan ile bereketin artacağı düşüncesi de takipçilere aşılanmaktadır. Böylece gelişen internet teknolojisinin sunduğu firsatları kullanan çevrimiçi dini akımlar, katı bir tüketimden akışkan tüketime yönelen faaliyetleriyle müşteri portföyünü genişletmeye devam etmektedir.

Sosyal ağlar, dijital dünyaya aidiyet bilincinin artması ve her geçen gün daha fazla insanın internet kullanıcısı olmasıyla birlikte gittikçe yalnızlaşan insana dijital kabilelere üye olma imkânı sunmaktadır. Bu durumu YÇA'lar hem aidiyet hem de tüketim açısından sundukları sanal sosyalleşme ortamıyla sağlamaya çalışmaktadır (Özbölük, 2019: 154-7). Bu çerçevede arayış içindeki kişinin aidiyet ve sosyalleşme ihtiyacına hitap eden 'FS Yaşam Çiçeği', sembollerin gündelik yaşamdaki gücünü ve bağlayıcı niteliğini kullanmaktadır (Öztürk, 2014: 302). Buradaki dinsel semboller ile uzak doğu pagan öğretilerinin aktarıldığı görülmektedir. ${ }^{21}$ Ayrıca 'şifa' adı altında yapılan kodlamalar, uygulamalar ile dinsel temalı sembol ve ürünler, bu topluluğun yeni çağ akımları arasında değerlendirilmesini gerektirmektedir.

Doğu dinlerinin öğretilerinden esinlenerek çeşitli inanç ve yönelimleri barındıran Altın Çağ Şifa Teknikleri’nin çevrimiçi dini faaliyetleriyle kültlere özgü nitelikler taşıdığı görülmektedir. Kendisini ‘Allah'ın memuru' ilan eden Altın Çă̆ Şifa Teknikleri kurucusu Ferhan Sezer 'danışman patlama çağında' (Bauman, 2013: 265; Bauman, 2015) eğitim danışmanı ve şifa uzmanı olarak hem yüzyüze hem de çevrimiçi eğitimler düzenlemektedir. Geniş kitlelere ulaşmak için ücretsiz hediye seans ya da canlı yayınların yanı sıra, ücretli şifa eğitimleri ve şifa kodlu ürün satışları da yapmaktadır. Böylece seküler söylemlerle örüntülenmiş ve bireye özgü inanç

\footnotetext{
19 (Erişim: 7 Eylül 2021).https://www.Instagram.com/p/CDKY_OBj9JQ/

${ }^{20}$ (Erişim: 11 Eylül 2021).https://www.Instagram.com/p/CTXFDtNjEfo/

${ }^{21}$ Lacivert. "New Age Kültleri', (Erişim 2 Eylül 2021).

https://www.lacivertdergi.com/dosya/2020/11/20/new-age-kultleri
} 
paketleri ile özelleştirilen; dini olan ile seküler olanın içiçe geçtiği (Beck, 2011: 10) ruhsallık formları ortaya çıkmaktadır.

YÇA’nın modern bireylere sunduğu en önemli konfor alanı, Grace Davie'nin 'ait olmadan inanma' olarak kavramsallaştırdığı seküler maneviyat formlarını hayatlarına uyarmalarına imkân sağlamasıdır. Yeni çağ akımlarının dini alanda konforun yanında bireysel huzur ve kendini ifade edebilme gücü vadetmesinin, postmodern dönemde dini motifli seküler akımların yükselişine zemin hazırladığı anlaşılmaktadır. Kurumsallaşmış dinden uzak pagan öğretileri dini mahiyette icra etmediklerini ifade etseler de Ferhan Sezer Altın Çağ Şifa Teknikleri Akımı'nın dünyadaki örneklerinde olduğu gibi Uzak Doğu dini öğretilerinden derlenen söylem ve eylemler içerdiği; şifa teknikleri, kodlamalar, ürünler ve semboller ile tipik bir YÇA özelliği taşıdığı görülmektedir. Bu çerçevede Ferhan Sezer Altın Çağ Şifa Teknikleri, dijital uzamı aktif kullanarak çeşitli söylem ve içerikleri sosyal ağ hesaplarında paylaşmakta ve dini motifli içeriklerin çevrimdışı uzamdan çevrimiçi uzama intikalini sağlamaktadır. Kaybettiklerini düşündükleri anlamı dijital uzamda arayan modern bireyler; sosyalleşme, bireyselleşme ve kutsala dönüş formlarında çevrimiçi topluluklara yönelmeye devam etmektedir.

\section{Sonuç}

Modernleşme ve sekülerleşme süreçlerinin kurumsal dinlerin toplumsal hayattaki belirleyici gücünü zayıflatması, dinin bireysel alana çekilmesiyle yeni dini hareketler alanını ortaya çıkarmıştır. Kutsalın dönüşü ile dini anlayışta oluşan yeni tezahürler mistik ve paranormal inançlara ilgiyi artırmış ve birer telafi mekanizması olarak değerlendirilmiştir. Modern insan kutsaldan uzaklaştıkça manevi boşluğu ve anlam arayışını doldurmak için yeni kutsal rehberlere ihtiyaç duymaktadır. Bu amaçla faaliyetlerde bulunan YÇA'lar, Batı toplumunda ortaya çıkan ve zamanla tüm dünyaya yayılan senkretik ve eklektik oluşumlardır. YÇA öğretilerinin kaynakları Hint ve Uzak Doğu din ve felsefelerine dayanmakta, geleneksel dinlere karşı anlam arayışında olan bireye ezoterik bilgiler sunmaktır. Yeni çağ akımları küreselleşen dünyada her türlü inanca hitap etmekte ve mistik öğretilerle dini kavramları sentezleyerek yeni bir dinsel alan oluşturmaktadır. YÇA, spiritüel ve mistik olguların yeni form kazanmasıyla modern topluma sunulan bireyselleştirilmiş bir dini temsil etmektedir. Kişiselleştirilmiş dinin bir çeşidi olan YÇA, yeni dini hareketler içinden doğmakla birlikte yoga, meditasyon, kozmik enerji, neo-paganizm, reiki, eft, biyoenerji ve şifa enerjisi gibi pek çok inanç ve uygulamayı kapsamaktadır.

Turkish Academic Research Review - Türk Akademik Araştırmalar Dergisi https://dergipark.org.tr/tr/pub/tarr 
Tarih boyunca olduğu gibi günümüzde de insanın anlam arayışına en güçlü yön vericilerden biri olan din, modern dönemde kutsalın yeniden sahneye çıkışı ile yerini dinimsi şifa gruplarına ve kültlerine bırakmıştır. Modern şifa yönelimleri olarak tanımlanan enerji şifacılığı uygulamalarının sayısı her geçen gün artmaktadır. Şifa kültleri ile paranormal inanç ve uygulamalar, hayatını anlamlandırma arayışı içindeki insanın, modern zamanların sorunlarıyla başa çıkmak ve problemlerini çözmek için yöneldiği alternatif oluşumlar arasındadır. Maddi ve manevi şifa arayışındaki yalnız insan, yeni inanış biçimleri ile bedensel ve ruhsal açıdan rahatlamaya yönelik teknik ve uygulamalara teşvik edilmektedir. Kutsalın şemsiyesi altında toplanan yalnız insan yalnızlığını şifa kültleri aracılığıyla gidermenin yollarını aramaktadır. Yeni medya ve özellikle sosyal medya araçları ile faaliyetlerini geniş kitlelere duyuran yeni dini akımlar, modern insanın anlam boşluklarını kişisel gelişim ve şifa dağıtma seanslarıyla doldurmayı amaçlamaktadır. Dinlerin dijital uzamdaki temsili ya da görünürlüğü, toplu ibadet, dua ve şifalanma gibi çalışmalarla gündeme gelmelerine neden olmuştur. YÇA kapsamındaki dini topluluklar, dijital uzam üzerinden yayılarak çevrimdışı ritüelleri çevrimiçi ritülellere dönüştürmektedir. Dinin siber uzamda kendisine yer açması, bir taraftan bireylerin kutsalla ilişkisini pekiştirerek anlam arayışına alternatifler sunarken, diğer taraftan yeni çağ akımlarının beraberinde getirdiği mistifikasyon alanı, modern şifacılık adı altında şifa kültleri oluşturarak bolluk ve bereket taleplerine dijital çağın imkânlarıyla cevap vermeye çalışmaktadır.

Bireyin anlam arayışının hayat boyu devam etmesi, modern dünyanın yeni soru ve sorunlarıyla başa çıkmak için manevi destek ihtiyacını sürekli tazelemesine yol açmaktadır. Modern hayatın zorluklarıyla mücadele eden birey, her ne kadar kişisel sorumluluklarını yerine getirmiş olsa da kendisini manevi yönden yalnız, desteksiz ve yetersiz hissetmekte; bu ihtiyacını gidermek içinse alternatif anlam arayışlarına yönelebilmektedir. Bu süreçte kurumsallıktan uzak ve karizmatik bir otorite anlayışı içermeyen yeni çağ akımları, dindar olmayan bireyler gibi dindar bireylerin de dikkatini çekmektedir. Bu durumdaki bireyler, bir taraftan kurumsal bağlılıklarının gerektirdiği ibadetleri sembolik olarak yerine getirirken diğer taraftan yeni maneviyatçı oluşumların ritüllerine de ihtiyaç duyabilmektedir. Sözgelimi Müslüman bir kişi, daha fazla huzura erişeceği inancı ile namaz kıldığı odaya şükür frekansı temalı tablo asarak modern bir şifalanma ritüeline katılabilmektedir. Dolayısıyla dindar bireylerin kurumsal dini bağlılıklarının yanında, yeni maneviyatçı yönelimleri de olabilmektedir.

Türkiye'de kişisel gelişim ve şifacılık olarak adlandırılan ve dünyada bir ilk olarak nitelendirilen Altın Çağ Şifa Teknikleri, hitap ettiği kesime hem seküler hem 
de dinsel bir üslup kullanarak söylem, sembol ve eylemleri ile cennetimsi bir yaşam vaadinde bulunmaktadır. Bu kapsamda hareketin kurucusu Ferhan Sezer yaşam çiçeği sembolünü beden ve yaşam şifası için kullanılabilir teknikler haline getirerek hem kolektif hem de çevrimiçi danışmanlık ve eğitimler sunmaktadır. Beyin, beden şifası, su ile şifa, şifalı kodlamalı sözler ve ürünler, ruhsal, enerjik, frekans ve titreşimler ile uygulamalar kullanmaktadır. Enerji şifacılığı ve frekans temalı Altın Çağ Şifa Teknikleri ile şifalı sözler paylaşmakta, tekrarlandığı takdirde yaşamın değişeceği garantisini demo ya da ücretli eğitimler ve seanslar ile sağlamaktadır. Dünyanın karmaşası karşısında insanları içlerindeki cenneti keşfetmeye çağırdığını belirten Ferhan Sezer, hakiki insan olma ve hakikati yakalayabilme yolunda arınmayı ve dünyada cenneti yaşamayı vadetmektedir. $\mathrm{Bu}$ amaçla düzenlediği ritüellerini çevrimiçi uzamda (Instagram), F. S. Atın Çağın şifa teknikleri, yaşam çiçeği ile beden şifası ve kodlamalar başlıkları altında paylaşmaktadır. Instagram hesabındaki Ferhan Sezer Altın Çağın Şifa Teknikleri, FS Yaşam Çiçeği Şifası sayfasında yer alan 548 gönderiden yaşam çiçeği ile şifalanma, para okulu, özel kodlamalı altın çağ şifa takıları olarak üç kategoride görsel ve metinsel paylaşımlara yer vermektedir. Hareket, paylaşımlarında kullandığı dil ve söylemlerinin ('Cennetten güne uyanıyorum', 'Meccanen şükür frekansındayım') yanı sıra, satılan ürünlerdeki (yaşam çiçeği tasarımlı tablo, cüzdan ve kolyeler) sembolleri ile paganist ve Uzak Doğu felsefesinin mistik yapısıyla örtüşmektedir. Ayrıca okültist ve ezoterik bir misyon da içermektedir. Yeni çağ akımlarındaki gibi bu oluşumun da insanı merkeze alarak evrendeki enerji ile şifalanma teknikleri sunması, kurtuluş reçetesi ve içsel uyanış vadetmesi ile dini bir hareket mi yoksa akım mı olduğu konusu tartı̧maya açıktır. Merkezi bir yönetim ve karizmatik bir liderden yoksun olması nedeniyle dini bir hareket olarak görülmese de seküler maneviyatçı, dini/tinsel bir alt kültür özelliği taşıması bakımından dini bir karaktere ya da yapılanmaya sahip görünmektedir.

\section{Kaynakça}

Akgül, M. (2017). Dijitalleşme ve Din. Marife Dini Araştırmalar Dergisi, 17/2, 191-207.

Albayrak, A. (2016). Alevi Meşrep Bir Tarikat: Galibilik. Türkish Studies, 11/17, 267-282.

Arslan, M. (2006). Değişim Sürecinde Yeni Dindarlık Formları: Yeniçağ İnanışları Örneği. Değerler Eğitimi Dergisi, 4/11, 9-25.

Arslan, M. (2015). Postmodern Yeni Dinsel Kimlik ve Paranormal İnançlar. Milel ve Nihal, 12/2, 55-72.

Turkish Academic Research Review - Türk Akademik Araştırmalar Dergisi https://dergipark.org.tr/tr/pub/tarr 
Aslan, R. (2016). Hekimlikte Alternatif ve Tamamlayıcı Tıbbi Yaklaşımlar. Kocatepe Veteriner Dergisi, 9/4, 363-371.

Aubyn, L. St. (1998). New Age: Yeni Çăg Akımı. (Çev. N. Mines ve E. Arısoy). İzmir: Ege Meta Yayınları.

Aydın, C. (2015). Insanın Anlam Arayışı ile Yeniçă̆ İnançları Arasındaki İlişki (Yayınlanmamış Doktora Tezi). Ondokuz Mayıs Üniversitesi Sosyal Bilimler Enstitüsü Felsefe ve Din Bilimleri Anabilim Dalı, Samsun.

Aysoy, M. (2013). Şifa Bu Değil: Modernliğin Ara Yüzü: Alternatif Tıp. İstanbul: Kaknüs Yayınları.

Bahadur, M. ve Çapcioğlu, İ. (2021). Yeni Dini Hareketlerde Çevrimiçi ve Çevrimdışı Yönelimler: Sahaja Yoga Örneği. İslami Araştırmalar Dergisi, 32/2, 37286.

Başkaya, Ş. (2006). New Age Hareketi: Modern Bir Dinsellik Biçiminin SosyoKültürel Analizi (Yayımlanmamış Yüksek Lisans Tezi). Marmara Üniversitesi Sosyal Bilimler Enstitüsü İlahiyat Anabilim Dalı Din Sosyolojisi Bilim Dalı, İstanbul.

Bauman, Z. (2013). Postmodernizm Hoşnutsuzlukları. (Çev. İ. Türkmen). İstanbul: Ayrıntı Yayınları.

Bauman, Z. (2015). Akışkan Modern Dünyada Kültür. (Çev. İ. Çapcıoğlu ve F. Ömek), Ankara: Atıf Yayınları.

Beck, U. (2011). Risk Toplumu- Başka Bir Modernliğe Doğru. (Çev. K. Özdoğan ve B. Doğan). İstanbul: İthaki Yayınları.

Beckford, J. A. (1987). New Religions, An Overview, Encyclopedia of Religion, (Ed. Mircae Eliade) C. X, New York.

Berger, P. L. (2011). Kutsal Şemsiye: Dinin Sosyolojik Teorisinin Ana Unsurları. (Çev. A. Çoşkun). İstanbul: Rağbet Yayınları.

Berger, P. L. ve Luckmann, T. (2015). Modernite Çoğulculuk ve Anlam Krizi. (Tür. Söy. M. Derviş Dereli). Ankara: Heretik Yayıncılık.

Biçer, R. (2006). Heretik Bir New Age: Dünya Kardeşlik Birliği Mevlana Yüce Vakfi. Ekev Akademi Dergisi, 10/29, 27-50.

Campbell, H. (2006). Religion and Internet: Considering the Online-Offline Conncetion, Centre for the study of Communication and Culture, 25/1, 3-24.

Campbell, H. (2012). Religion and Internet: A Microcrocosm for Studying Internet Trends and Implications, New Media and Society, 0, 1-15.

Campbell, H. ve Lövheim, M. (2011). Religion and Internet. Information Communication and Society, 14/8, 1083-1096.

Cereci, S. (2020). New Media for New Globalist Strategy. New Media and Strategies Dijital Media. (Ed. E. Karakoç ve H. Çiftçi), 5-31. Ankara: İKSAD. 
Çağrıcı, M. (2010). Şükür. DİA. İstanbul: TDV Yayınları, 39, 259-261.

Çamdereli, M. (2018). Din Ekranda Nasıl Durur? Medyada Dinin Popüler Temsilleri. İstanbul: Ketebe Yayınları.

Çapcioğlu, İ. (2016). Yeni Dini Hareketler. Dini Gruplar Sosyolojisi. (Ed. N. Akyüz), 325-340. Ankara: Ankara Üniversitesi Uzaktan Eğitim Merkezi Yayınları.

Çapcıŏlu, İ. (2017a). Modernleşen Türkiye'de Din ve Toplum. Ankara: Otto Yayınları.

Çapcioğlu, İ. (2017b). Modernleşme, Sekülerleşme ve Din. Din Sosyolojisi (Ed. O. Eyüpoğlu), 141-152. Bişkek: İz Basma.

Çapcıoğlu İ. (2020a). Akışkan Zamanlarda 'Değer'li Yaş̧amak. Ankara: DİB Yayınları.

Çapcioğlu, İ. (2020b). Pandemi, Post-Pandemi ve Yeni Dindarlık Modelleri. TRT Akademi Dergisi Salgın Yayıncılı̆̆ Kovid-19 Özel Sayısı, 5/10, 80-89.

Çapcıoğlu, İ. ve Anık, H. (2021). Sanayi Devriminden Endüstri 4.0'a: Dijitalleşme ve Dijital Dünyada Dinin Statüsü. Tevilat: Selçuk Üniversitesi İslami Ilimler Fakültesi Dergisi, 2/1, 27-43.

Çapcığlu, İ. ve Kaya, E. (2021). Pandemi Döneminde Türkiye'de Dini Hayat: Din Görevlileri Örneğinde Dini Hayata Genel Bir Bakış. Ankara: Bizim Büro Basımevi.

Çapcıoğlu, İ. ve Yürük, T. (2010). Modern Dünyada İnsanın Anlam Arayışına Teolojik Katkı: Hz. İbrahim Kıssası Örneği. BIDDER Sosyal Bilimler Dergisi, 1/2, 21-31.

Davie, G. (1994). Religion in Britain since 1945: Believing without Belonging. Oxford: Blackwell Publications.

Davie, G. (2005). Din Sosyolojisinde Yeni Yaklaşımlar: Batılı Bir Bakış. Çev. M. Akgül ve İ. Çapcıŏlu. Ankara Üniversitesi İlahiyat Fakültesi Dergisi, 46/1, 201214.

Dawson, L. L. ve Hennebry, J. (2003). Cults and New Religious Movements: A Reader. New Religions and the Internet: Recruiting and New Public. Wiley Blackwell, 270-312.

Dereli, M. D. (2020). Sanala Veda: Sosyal Medya ve Dönüşen Dindarllk. Ankara: Nobel Yayıncilik.

Dereli, M. D. (2021). Nostalji, Mit ve Gerçeklik Sarkacında Salgını Anlamlandırma: Dini Toplulukların Çevrimiçi Anlatılarının Söylem Analizi. Rutin ve Hayret Bir İmkân ve Imtihan Olarak Pandemi. (Ed. F. Kararaslan ve S. Doğan), 169210. İstanbul: DBY Yayınları.

Turkish Academic Research Review - Türk Akademik Araştırmalar Dergisi https://dergipark.org.tr/tr/pub/tarr 
Dick, H. ve Peter, M. (2002). Why Do Churches Become Empty, While New Age Grows? Secularization and Religious Change in the Netherlands, Journal for the Scientific of Religion, 41/3, 455-473.

Doğan, E. (2020). Türkiye'de New Age Hareketi: Şifact Gruplartn SosyoEkonomik ve Kültürel Tabanı Üzerine Sosyolojik Bir Inceleme (Yayınlanmamış Yüksek Lisans Tezi). Uludağ Üniversitesi Sosyal Bilimler Enstitüsü, Felsefe ve Din Bilimleri Anabilim Dalı, Bursa.

Erdoğan, Z. ve Çınar, S. (2011). Reiki: Eski Bir İyileștirme Sanatı -Modern Hemșirelik Uygulaması. Kafkas Tip Bilimleri Dergisi, 1/2, 86-91.

Erten, R. (2020). Hristiyanlık'ta İslamiyet'te Şifa ve Bu Dinlere İnananların Sağlık Konusuna Bakışları. Kalemname, 5/10, 387-443.

Faruk, K. (2015). Post-Seküler Din Halleri ve Dinin Dijitalleşmesi. Dijitalleşen Din Medya ve Din 2. (Ed. M. Çamdereli, B. Önay Doğan ve N. Kocabay Şener), 13-44. İstanbul: Köprü Kitap.

Furseth, I. ve Repstad, P. (2011). Din Sosyolojisine Giriş: Klasik ve Çağdaş Kuramlar. (Çev. İ. Çapcıoğlu ve H. Aydınalp). Ankara: Birleşik Yayınevi.

Gazneli, D. ve Kılıç, N.S. (2020). Din Eksenli Tüketimin Yeni Medyadaki Görünümleri: Tüketim Kültürü Bağlamında Değerlendirme. Medya ve Din Araştırmaları Dergisi, 3/2, 197-216.

Günay, N. (2003). Dünya Kardeşlik Grubu (Piramitçiler veya Mevlanacılar) Üzerine Bir İnceleme. Süleyman Demirel Üniversitesi Illahiyat Fakültesi Dergisi, $11 / 2,1-60$.

Günay, N. (2011). Türkiye'de Yeniçăg Inançları. Isparta: Manas Yayınevi.

Gürbüz, G. (2020). Yeni Çağ İnanışları: Faaliyet Alanları, etkileri ve Görünümlerinin Sosyolojik Analizi (Antalya Örneği) (Yayınlanmamış Yüksek Lisans Tezi). Akdeniz Üniversitesi Sosyoloji Ana Bilim Dalı, Antalya.

Gürbüz, G. (2021). Arayıştan Uyanışa, Şifadan Estetiğe Yeni Çağ İnançları. Sakarya Üniversitesi Illahiyat Fakültesi Dergisi, 23/43, 19-51.

Haberli, M. (2019, Aralık). Dijital Çağda Din ve Dindarlığın Dönüşümü. Medya ve Din Araşttrmaları Dergisi, 2/2, 307-315.

Hanegraff, W. J. (1996). New Age Religion and Western Culture: Esotericism in the Mirrorof Secular Thought. Leiden, New York: E. J. Brill.

Hanegraff, W. J. (1999). New Age Spiritualities as Seculer Religion: A Historian Perspective. Social Compass, 46/2, 145-160.

Kaplan, M. (2015). Geleneksel Tedavi Pratikleri ve Uygulayıcıları: Kadın Şifacılar. Milli Folklor, 27/108, 189-196. 
Kara, Z. (2017). Dijital Sosyoloji. Sosyoloji Divanı Sosyoloji Dergisi, 5/9, 920.

Kirman, M. A. (2010). Yeni Dini Hareketler Sosyolojisi. Ankara: Birleşik Kitabevi.

Köse, A. (2019). Milenyum Tarikatlart: Batıda Yeni Dini Akımlar. İstanbul: Timaş Yayınları.

Luckmann, T. (2016). Görünmeyen Din: Modern Toplumda Din Sorunu. (Çev. A. Çoşkun, F. Aydın ve O. Çoşkun). 2. Baskı, İstanbul: Rağbet Yayınları.

Mirza, G. A. (2018). Yeni Dinselleşme Eğilimleri ve Maneviyat Arayışları. İstanbul: Boğaziçi Üniversitesi Yayınları.

Narmanlıŏlu, H. (2015). Sanal Cematte Çevrimiçi İbadet. Dijitalleşen Din Medya ve Din 2. (Ed. M. Çamdereli, B. Önay Doğan ve N. Kocabay Şener), 69-108. İstanbul: Köprü Kitapları.

Özbölük, T. (2019). Sahipliğin Sıkıcılığından Erişimin Özgürlüğüne Kaçış: Akışkan Tüketime İlişkin Kavramsal Çerçeve. Journal of Economy Culture and Society, 59, 143-162.

Öztürk, G. (2014). Reklamlarda Dinsel Sembollerin Kullanımı. Medya ve Din. (Ed. M. Çamdereli, B. Önay Doğan ve N. Kocabay Şener), 289-318. İstanbul: Köprü Kitapları.

Parladır, H. S. ve Özkan, D. (2015). Sosyal Bilimlerde Paranormal İnançlara Dair Çalışmalar: Sekülerleşme ve İnanç İkileminde Modern Birey ve Toplum. Celal Bayar Üniversitesi Sosyal Bilimler Dergisi, 13/1, 172-202.

Paul, H. (1999). The New Age Movement: The Celebration of the Self and the Sacralization of Modernity. Oxford: Blackwell Publications.

Pearson, J. (2002). Belief Beyond Boundaries: Wicca, Celtic Spirituality and the New Age (Religion Today-Tradition, Modernity \& Change). London: Ashgate Publishing.

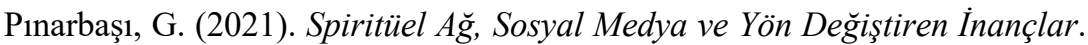
İstanbul: Okur Akademi.

Sevgi, A. (2011). Yeni Dini Akımların Temel Görüşleri ve İslam (Yayınlanmamış Yüksek Lisans Tezi). Yüzüncü Yıl Üniversitesi Sosyal Bilimler Enstitüsü Temel İslam Bilimleri Anabilim Dalı, Van.

Sutcliffe, S. J. (2006). Re-Thinking "New Age" as a Popular Religious Habitus: A Review Essay on the Spiritual Revolution. Method \& Theory in the Study of Religion, 18/3, 294-314.

Şentürk, R. (2004). Yeni Din Sosyolojileri. İstanbul: Gelenek Yayıncılık.

Turkish Academic Research Review - Türk Akademik Araştırmalar Dergisi https://dergipark.org.tr/tr/pub/tarr 
Tosun, N. B. ve Cesur, D. K. (2018). Tüketim Paranormali: Gösterişçi Tüketim ve Paranormal İnanç İlişkisi. Marmara Üniversitesi Öneri Dergisi, 13/49, 167-186.

Touraine, A. (2016). Modernliğin Eleştirisi. (Çev. H. Tufan). İstanbul: Yap1 Kredi Yayınları.

Uluç, Ö. (2013). Yeni Dini Hareketler. İstanbul: Yarın Yayınları.

Ünal, M. S. (2011). Dinsel Bireycilik. İstanbul: Açılım Kitap.

Vardi, R. (2015). Dini organizasyonların Dijitalleşmesi. Dijitalleşen Din Medya ve Din 2. (Ed. M. Çamdereli, B. Önay Doğan ve N. Kocabay Şener), 109-150. İstanbul: Köprü Kitap.

Varlık, S. (2019). Türkiye'de Din Dışı Spiritüal Akımlar Üzerine Bir Araştırma (Yayınlanmamış Yüksek Lisans Tezi). On Sekiz Mart Üniversitesi Sosyal Bilimler Enstitüsü Felsefe ve Din Bilimleri Anabilim Dalı, Çanakkale.

Wagner, R. (2012). Godwired Religion, Ritual and Virtual Reality. New York: Routledge.

Weber, M. (2010). Protestan Ahlakı ve Kapitalizmin Ruhu. Ankara: Alter Yayıncılik.

Weber, M. (2011). Sosyoloji Yazıları. (Çev. T. Parla). İstanbul: Deniz Yayınları.

Wynee, A. (2017). Enerji Şifası. (Çev. E. Boyacıoğlu). 1. Baskı. İstanbul: Ganj Yayıncilık.

Yalvaç, A. H. (2021a). Modern Şifacılık Yönelimlerinden Enerji Şifacılığı Uygulamaları. Türkiye Din Eğitimi Araştırmaları Dergisi, 11, 233-267.

Yalvaç, A. H. (2021b). Modern Şifacılık Yönelimleri. Recep Tayyip Erdoğan Üniversitesi Illahiyat Fakültesi Dergisi, 19, 291-324.

Zuckerman, P. (2010). Din Sosyolojisine Giriş. (İ. Çapcığlu ve H. Aydınalp). 3. Baskı, Ankara: Birleşik Yayınları.

\section{Web Kaynakları}

Ferhan Sezer (Erişim 21 Eylül 2021), http://ferhansezer.com/ferhan-sezeritaniyalim/

“Ferhan Sezer'i Tanıyalım”. (Erişim 31 Ağustos 2021).

http://ferhansezer.com/ferhan-sezeri-taniyalim/

Ferhan Sezer. "Eğitim”. (Erişim 31 Ağustos 2021).

http://ferhansezer.com/ferhan-sezeri-taniyalim/

“Meccanen”. (Erişim 1 Eylül 2021). http://www.lugatim.com/s/meccanen

“Meccanen”. (Erişim 1 Eylül 2021). https://sozluk.gov.tr/ 
Lacivert. "New Age Kültleri”. (Erişim 2 Eylül 2021).

https://www.lacivertdergi.com/dosya/2020/11/20/new-age-kultleri

(Erişim 1 Eylül 2021). https://www.Instagram.com/p/CLAZFuvl5v6/

(Erişim 2 Ağustos 2021). https://www.Instagram.com/p/CSmfGNuDx7G/

(Erişim 2 Ağustos 2021). https://www.Instagram.com/p/CLAZFuvl5v6/

(Erişim 2 Ağustos 2021). https://www.Instagram.com/p/CTFTJZKDleE/

(Erişim 14 Ağustos 2021). https://www.Instagram.com/p/CRisXk5rhBE/

(Erişim 14 Ağustos 2021). https://www.Instagram.com/p/CLtzF1SLDm5/

(Erişim 2 Eylül 2021). https://www.Instagram.com/p/CJ9g4smrizA/

(Erişim 5 Eylül 2021). https://www.Instagram.com/p/COBMWzUDFpZ/

(Erişim 7 Eylül 2021). https://www.Instagram.com/p/CDKY_OBj9JQ/

(Erişim 11 Eylül 2021). https://www.Instagram.com/p/CTXFDtNjEfo/

Turkish Academic Research Review - Türk Akademik Araştırmalar Dergisi https://dergipark.org.tr/tr/pub/tarr 